In cooperation with the National Park Service

\title{
Surveillance for White-Nose Syndrome in the Bat Community at El Malpais National Monument, New Mexico, 2011
}

By Ernest W. Valdez

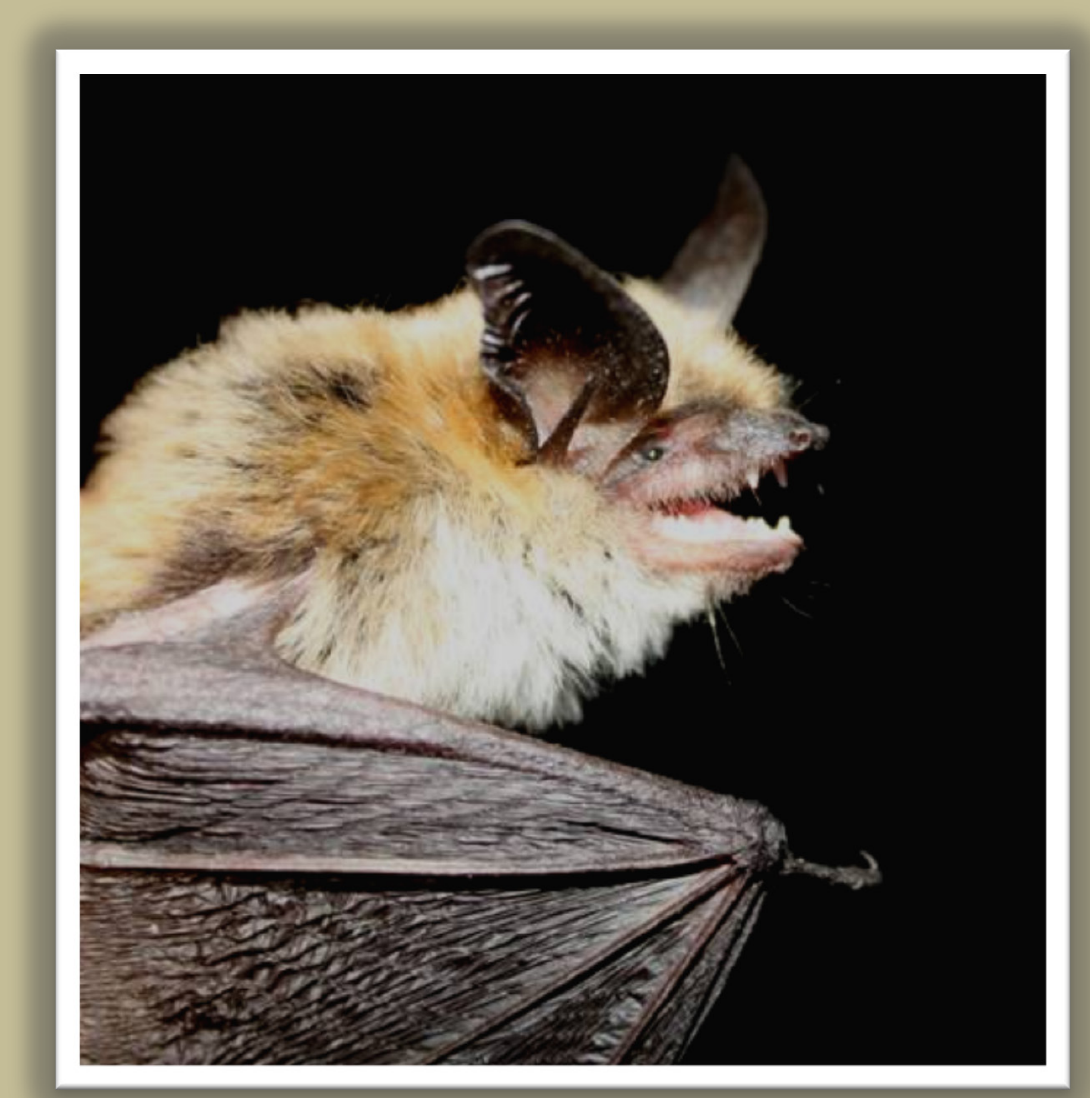

Open-File Report 2012-1097

U.S. Department of the Interior

U.S. Geological Survey 
Cover photograph: Myotis evotis (Long-eared Myotis), photo by E.W. Valdez 


\section{Surveillance for White-Nose Syndrome in the Bat Community at El Malpais National Monument, New Mexico, 2011}

By Ernest W. Valdez

Open-File Report 2012-1097

U.S. Department of the Interior

U.S. Geological Survey 


\section{U.S. Department of the Interior \\ KEN SALAZAR, Secretary}

\section{U.S. Geological Survey \\ Marcia K. McNutt, Director}

U.S. Geological Survey, Reston, Virginia 2012

For product and ordering information:

World Wide Web: http://www.usgs.gov/pubprod

Telephone: 1-888-ASK-USGS

For more information on the USGS-the Federal source for science about the Earth, its natural and living resources, natural hazards, and the environment:

World Wide Web: http://www.usgs.gov

Telephone: 1-888-ASK-USGS

Suggested citation:

Valdez, E.W., 2012, Surveillance for White-Nose Syndrome in the bat community at El Malpais

National Monument, New Mexico, 2011: U.S. Geological Survey Open-File Report 2012-1097, 37 p.

Any use of trade, product, or firm names is for descriptive purposes only and does not imply endorsement by the U.S. Government.

Although this report is in the public domain, permission must be secured from the individual copyright owners to reproduce any copyrighted material contained within this report. 


\section{Contents}

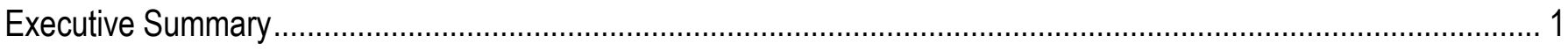

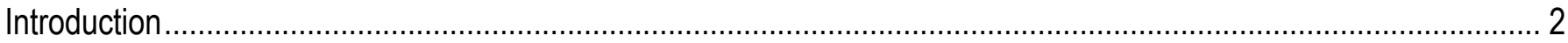

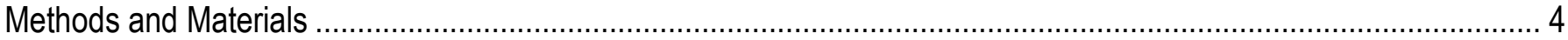

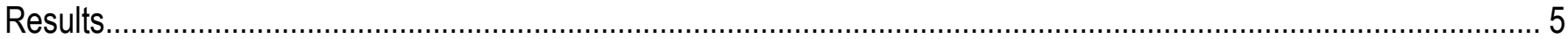

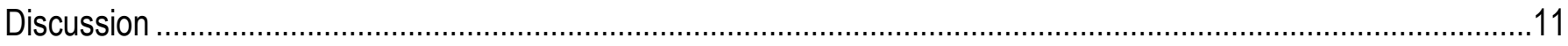

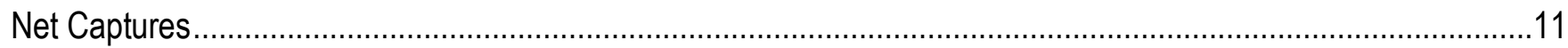

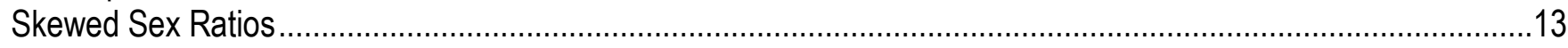

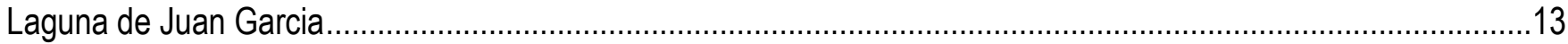

Effects of Wildfires on Bats and Potential Impacts to Laguna de Juan Garcia..................................................15

Overview of Bats at ELMA and Adjacent Lands and Some Recommendations...............................................15

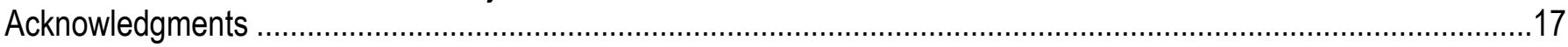

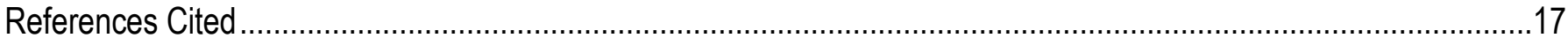

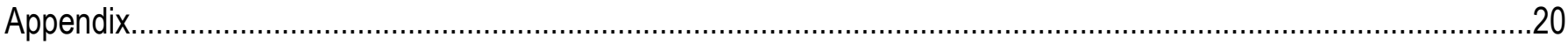

\section{Figures}

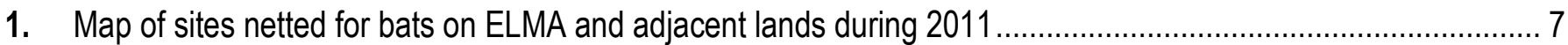

2. Wind speeds recorded between March 1 and May 30, 2011, 2000, and 1999 at El Malpais National Monument ................................................................................................................................. 12

3. Amount of precipitation (inches) recorded at El Malpais National Monument between March 1 and

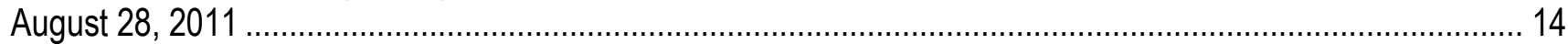

\section{Tables}

1. Dates, level of net effort, and number of bats captured in mist nets at each net location during $2011 \ldots \ldots \ldots \ldots \ldots . . .6$

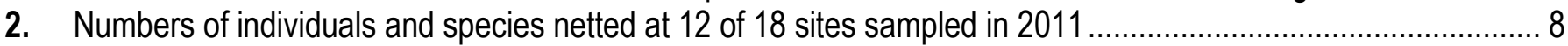

3. Numbers of individuals and species netted at 12 of 18 sites sampled in 2011 ............................................. 8

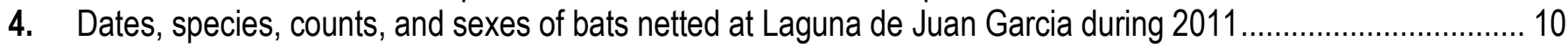




\title{
Surveillance for White-Nose Syndrome in the Bat Community at El Malpais National Monument, New Mexico, 2011
}

\author{
By Ernest W. Valdez
}

\section{Executive Summary}

White-nose syndrome (WNS) is a disease that has been devastating to populations of hibernating bats in the eastern United States and has spread westward. It was first reported in the winter of 20062007 near Albany, New York. Since then, it has spread westward to western Kentucky and Tennessee, and in 2010, the WNS-related fungus (Geomyces destructans) was documented in western Oklahoma. Given the proximity of $G$. destructans to El Malpais National Monument and its effects on hibernating bats, the monument contacted the U.S. Geological Survey (USGS) to conduct an assessment for the presence of this fungus or related disease on bats. During the late winter and early spring of 2011, the USGS Arid Lands Field Station initiated mist-netting efforts at El Malpais National Monument and on adjacent lands belonging to Bureau of Land Management (BLM) and U.S. Forest Service (FS). Field efforts were conducted during spring and summer but were concentrated in the early spring, when the presence of the fungus or its effects would be detectable compared to warmer and later periods of the spring and summer. However, irregular wind speeds, as well as cold temperatures and snow, likely had a negative effect on net captures and success during the spring. Nonetheless, during this assessment, 421 bats belonging to 8 species were documented at El Malpais National Monument and adjacent lands. None of these captures showed evidence for the presence of $G$. destructans or white-nose syndrome, but it is possible that the subtle signs of some infections may not have been observed.

Laguna de Juan Garcia, a large pool located in the northwestern corner of El Malpais National Monument, was netted 4 times throughout the spring and summer and a total of 155 bats were captured. Laguna de Juan Garcia also had the greatest number of captures (79 bats) during one night compared to the other sites netted and had the greatest species diversity of 8 species netted, not including Euderma maculatum (Spotted Bat) that was detected by its audible calls as it flew overhead. Laguna de Juan Garcia is an important site to bats because of its accessibility by all known occurring species, including the less-maneuverable Tadarida brasiliensis (Brazilian Free-tailed Bat) that is known to form large colonies in the park. Laguna de Juan Garcia is also important as a more permanent water source during drought conditions in the earlier part of the spring and summer, as observed in 2011.

Although efforts during 2011 did not result in the detection of G. destructans or WNS on bats at El Malpais National Monument and adjacent lands, monitoring for the spread of this disease should continue. Such efforts should include mist-netting as well as subterranean monitoring and locating unknown hibernacula. In addition to monitoring for WNS, future studies also should include understanding use of forests and woodlands as summer roosts by bats; investigating ecological and economic impacts of bats as insect predators; and investigating the effects of fire on the landscape and 
its impacts to bats. These will allow future studies to provide better insight needed for habitat management at the Monument.

\section{Introduction}

In 1999 and 2000, Valdez and others (2002) conducted a survey of bats at El Malpais National Monument (ELMA) and adjacent lands, and documented 16 species of bats: Antrozous pallidus (Pallid Bat), Corynorhinus townsendii (Townsend's Big-eared Bat), Eptesicus fuscus (Big Brown Bat), Euderma maculatum (Spotted Bat), Lasionycteris noctivagans (Silver-haired Bat), Lasiurus cinereus (Hoary Bat), Myotis auriculus (Southwestern Myotis), M. californicus (California Myotis), M. ciliolabrum (Western Small-footed Myotis), M. evotis (Western Long-eared Myotis), M. thysanodes (Fringed Myotis), M. volans (Long-legged Myotis), M. yumanensis (Yuma Myotis), Parastrellus hesperus (Canyon bat, formerly known as Pipistrellus hesperus, Western Pipistrelle), Nyctinomops macrotis (Big Free-tailed Bat), and Tadarida brasiliensis (Brazilian Free-tailed Bat). Twelve of these were reported from net captures, whereas the remaining four were documented by audible or ultrasonic call recordings (Valdez and others, 2002).

From the netting efforts during June 1 to August 18, 1999, Valdez and others (2002) amassed 30 net-nights across 10 sites and captured 232 bats belonging to 12 species. These included M. auriculus (4 males), M. californicus (2 males), M. ciliolabrum (21 males, 5 females), M. evotis (78 males, 10 females), M. thysanodes (7 males, 9 females), $M$. volans (16 males), L. cinereus (1 male), $L$. noctivagans (14 males), E. fuscus (44 males, 1 female), C. townsendii (1 male, 1 female), A. pallidus (5 males, 7 females), and T. brasiliensis (6 males). The most abundant species captured during 1999 included M. evotis (38 percent of all captures), E. fuscus (19 percent), M. ciliolabrum (11 percent), $M$. thysanodes and M. volans (each 7 percent), and T. brasiliensis (3 percent, Valdez and others, 2002). Of all the captures recorded for 1999, Valdez and others (2002) noted that none of the males or females captured in June showed signs of reproductive condition, but in July reported that some E. fuscus and L. noctivagans had swollen epididymides and recorded 6 A. pallidus and $2 \mathrm{M}$. thysanodes as pregnant or lactating.

From the netting efforts during May 16 to August 2, 2000, Valdez and others (2002) amassed 56 net-nights across 12 sites and captured 324 bats belonging to 12 species. These included M. auriculus (30 males, 2 females), M. californicus (1 male, 1 female), M. ciliolabrum (58 males, 3 females), $M$. evotis (59 males, 1 female), M. thysanodes (18 males, 18 females), M. volans (4 males), L. cinereus (2 male), L. noctivagans (97 males), E. fuscus (10 males, 10 female, 1 unknown sex), C. townsendii (1 male), A. pallidus (2 males, 4 females), T. brasiliensis (1 male), unidentified Myotis (1 unknown sex). The most abundant species captured during 2000 included M. ciliolabrum and M. evotis (each 19 percent of all captures), M. thysanodes (11 percent), M. auriculus (10 percent), and E. fuscus ( 7 percent; Valdez and others, 2002).

Although 30 percent of all captures were L. noctivagans, 85 of the 97 males netted were from one night and regarded by Valdez and others (2002) as migrants passing through the area. Similar to 1999, during July, 2000, Valdez and others (2002) also reported some E. fuscus and L. noctivagans as having swollen epididymides. However, Valdez and others (2002) noted several reproductive females during 2000, including a pregnant $M$. ciliolabrum and a likely pregnant $M$. thysanodes netted as early as June 5 at Cerro Colorado. Valdez and others (2002) also reported other reproductive females netted between 5 June and the first week of August, including 4 lactating A. pallidus; 9 pregnant, lactating, or post-lactating E. fuscus; 1 lactating M. californicus; 1 lactating M. ciliolabrum; and 13 pregnant, lactating, or post-lactating M. thysanodes, with most of these captured at Cerrito Comadre, Cerro Rendija, Cerro Lobo, and Prairie Dog Well I \& II net sites (Valdez and others, 2002). The only juvenile 
captured during both years of netting was a male $M$. thysanodes netted on July 31, 2000, at Cerro Rendija II (Valdez and others, 2002).

Since then, only a few efforts have been conducted to study or document bats at ELMA, although none were extensive as that by Valdez and others (2002). For example, Geluso and Bogan (2005) netted only a total of 9 net-nights at select areas in and around the park during their small mammal- and bat-trapping efforts in 2003 and 2004. In 2003, Geluso and Bogan (2005) captured 66 bats belonging to 6 species (that is, M. evotis (34 bats), M. thysanodes (7), M. volans (3), L. cinereus (1), E. fuscus (19), and C. townsendii (2)). In 2004, Geluso and Bogan (2005) documented 125 bats, of which 121 were based on captures of individuals belonging to 10 species (that is, M. californicus (1), M. ciliolabrum (3), M. evotis (16), M. thysanodes (11), L. cinereus (1), L. noctivagans (4), E. fuscus (5), C. townsendii (4), A. pallidus (1), and T. brasiliensis (64). In addition, of the 121 bats captured in 2004 by Geluso and Bogan (2005), 11 could only be identified as M. californicus/ciliolabrum because of difficulties in distinguishing the two species in the field. Overall, most of the captures recorded in 2004 were T. brasiliensis that were netted near the entrance of the lava-tube named "Bat Cave." An additional four E. maculatum were documented by their distinct audible calls in 2004 by Geluso and Bogan (2005). Unfortunately, no additional information on the sexes or reproductive conditions of bats captured in 2003 was reported, and only limited information was provided for 2004. For example, on May 27, 2004, Geluso and Bogan (2005) captured 16 bats at the entrance of Bat Cave, of which 10 represented "both sexes" belonging to T. brasiliensis, followed by 4 female $C$. townsendii and 2 male M. californicus/ciliolabrum. On August 27, 2004, Geluso and Bogan (2005) captured T. brasiliensis (41 males and 9 females). A single $M$. ciliolabrum was netted on the same evening, but the sex of the individual was not noted. No vouchers were collected during their study. In 2007, Wynne (2011) conducted lava-tube surveys at ELMA and documented a few roosting bats including C. townsendii and E. fuscus at Junction Cave, and T. brasiliensis at Bat Cave.

In 2007, WNS was first discovered in the early spring, affecting bats in caves near Albany, N.Y. (U.S. Fish and Wildlife Service, 2011). White-nose syndrome is a disease that affects hibernating bats and is caused by the fungus Geomyces destructans (Gargas and others, 2009; Lorch and others, 2011). This disease has been devastating populations of bat species that use caves and mines as hibernacula in the eastern United States, with instances of greater than 90-percent loss of some colonies (U.S. Fish and Wildlife Service, 2011). This disease is spreading to the West, mostly by direct bat-to-bat contact (Lorch and others, 2011). To date, there is no known cure for this disease, and there are no methods for stopping or slowing its spread among populations of bats. It is also reasonable to assume that spores of this fungus can be transmitted from hibernaculum to hibernaculum on fomites (an inanimate object that can transmit an infectious agent), such as shoes or clothing that come in contact with spores (U.S. Geological Survey, 2011). Thus, it is believed that human transmission of G. destructans can occur beyond the distances traveled by bats. Currently, WNS has been reported as far west as western Kentucky and Tennessee, and the occurrence of the causal fungal agent ( $G$. destructans; Lorch and others, 2011) has been documented in the panhandle of Oklahoma. The site where G. destructans was detected on bats in Oklahoma is approximately 200 miles (mi) (322 kilometers $(\mathrm{km})$ ) from the eastern border of New Mexico.

Unlike the states of the Great Plains and East, where species diversity ranges from a few species to about 15 (Sparks and Choate, 2000; Hall, 1981), New Mexico has 28 species of bats, not including the potential occurrence of M. lucifugus, and at least 16 of these species hibernate (Frey, 2004). Surprisingly, little information exists on the locations of hibernacula for most species that occur in New Mexico. However, a few species (for example $C$. townsendii) have been reported by Wynne (2011) as 
using lava-tubes, located at ELMA, as hibernacula, although both the vastness of the lava-tube system across the park and the amount of use by bats throughout is poorly known.

Personnel at ELMA have taken a proactive stance in documenting the occurrence of $G$. destructans and WNS by initiating field efforts in late 2010 and throughout 2011. These efforts involve lava-tube assessments conducted by cave and lava-tube specialist Dr. Diana Northup of the University of New Mexico, as well as mist-netting efforts conducted by the USGS. Using cave assessments to detect WNS provides a direct means of determining the presence of the disease and causative agent as well as insight on the use of this critical habitat that serves as hibernacula for bats. However, given the extensive nature of the lava-tube systems at ELMA, with many areas that likely have undiscovered hibernacula or are inaccessible to people, these lava-tube assessments may provide only limited information on the presence of WNS.

An additional concern with surveys of hibernacula is that surveys may have adverse effects on hibernating bats through disturbance of bats and depletion of their stored body fat. For these reasons, ELMA personnel wanted to also initiate spring mist-netting assessments of bats at water sites near habitat that serves or is likely to serve as hibernacula. By doing so, multiple species from potentially different hibernacula could be examined for the disease. Mist-netting is most effective when water sources are limited, thus concentrating bats at a specific location (Geluso and Geluso, 2012). In addition to documenting the presence of WNS, mist-netting efforts provide insight on a variety of natural history information such as habitat use, sex ratios, and time of emergence from hibernation. Information in all of these categories are poorly known for bats in the Southwest.

In light of population losses in eastern United States as a result of WNS, there has been more awareness on the economic and ecological importance of bats (Boyles and others, 2011). Data from this project will serve as a benchmark on the current status of bats in relation to the occurrence and spread of WNS, as well as provide information that can be compared against historic and future studies that will be needed to prepare and better manage bats should the disease occur at ELMA. The main objective of this study was to conduct surveillance, through mist-netting, for the presence of G. destructans (for example, visible hyphae growing on nose, ears and wings of bats) or other related evidence of WNS (for example, wing scarring) on bats emerging from their hibernacula. Secondary objectives included documenting the occurrence and relative abundance of bat species, especially those that may be regarded as species of concern or interest by the park (for example, C. townsendii).

\section{Methods and Materials}

To address the main objective of this study, efforts focused on net captures of bats and did not include acoustic monitoring, which was a component of the previous study by Valdez and others (2002). According to Geluso (2007), most bats in New Mexico hibernate between November and March, but this may vary according to species and geographic location within the state. However, because the exact time when bats emerge from their hibernacula at ELMA is unknown, the timing of netting efforts was also influenced by local weather conditions (that is, temperature, precipitation, and wind) that were conducive for successful netting and captures of bats. Therefore, netting during 2011 was initiated in early spring (March 29) and continued throughout the summer (August 5), but efforts were concentrated during spring (that is, March 20 to June 20), a time when bats are emerging from their hibernacula. This time period was also chosen to provide better opportunities in detecting visible signs of the fungus, such as the visible hyphae growing on nose, ears, and wings of bats (U.S. Fish and Wildlife Service, 2009), as well as wing scarring related to WNS as noted by Reichard and Kunz (2009).

In addition to weather conditions, phase of moon was taken into account for the selection of nights to net. According to Reith (1982) and Hecker and Brigham (1999), some temperate bat species 
alter their feeding behavior based on moon phase (for example, avoidance of areas exposed to bright and direct moonlight of a full moon). Therefore, netting efforts during 2011 also were scheduled on dates when moon phase and moon light would have the least potential influence on captures. During periods when there was bright moonlight, mist nets were placed in areas over water where neighboring trees provided shadows.

In general, locations of net sites were chosen based on the availability of unobstructed water surfaces and the proximity of these sites to areas of potential or documented hibernacula (for example, lava-tubes). However, many sites netted in 2011 had been sampled previously by Valdez and others (2002), with most located along the western and northwestern edges of ELMA, on lands managed by the Bureau of Land Management (BLM) and Forest Service (FS). Many of these sites were small metal stock tanks and contained water only intermittently. Laguna de Juan Garcia is the only known water source in the park that appears to hold water throughout the year; it is presumably re-charged by winter snow melt and seasonal rains, as observed in 2011 . This earthen pond (28 meters $(\mathrm{m}) \times 25 \mathrm{~m})$ is located near the northwestern boundary of ELMA and is situated within ponderosa pine forest and near transitional habitat of piñon-juniper woodland. The location of Laguna de Juan Garcia and its proximity to known and potentially unknown hibernacula sites provides an opportunity for greater likelihood of detection of WNS through mist-netting efforts. Unfortunately, the location of Laguna de Juan Garcia was unknown until after June 10; therefore, netting at this site was conducted on the last day of spring but continued throughout the summer.

Overall, bats were netted following general methods described by Kunz and others (2009). Nets were set and opened about 20-30 minutes before sunset and monitored until closure. Level of mistnetting effort was quantified by using the number of net-nights for each site (for example, 3 nets set for one night $=3$ net-nights; appendix). Number of nets at a site varied, depending on size and shape of the water source and number of investigators present to help process bats. Upon capture, bats were removed promptly, identified, and relevant data were recorded before they were released unharmed. Date, locality, number and size of nets, time of deployment and closure of nets, temperature, time of capture, species, sex and age were recorded on standardized data sheets and later transferred to an electronic database (Microsoft Excel format). Age was determined by examining epiphyseal ossification in the wing joints, as described by Brunet-Rossinni and Wilkinson (2009). White-nose syndrome decontamination protocols followed those of the U.S. Fish and Wildlife Service (2011). Capture and handling methods of bats followed a written protocol approved by the USGS Fort Collins Science Center, Animal Care and Use Committee. In the event of encountering evidence of G. destructans or WNS, all netting activity would cease and information would be presented to ELMA, New Mexico Game and Fish, and the USGS National Wildlife Health Center. Infected individuals would be submitted the USGS National Wildlife Health Center following instructions on their website (http://www.nwhc.usgs.gov/mortality_events/reporting.jsp).

Although some voucher specimens were taken in 1999 and 2000 from areas adjacent to ELMA, none were collected from the park during that time. Therefore, in 2011, select individuals were collected as representatives from the park to ensure correct identification of species or to document new records of occurrence. Bats were prepared as study skins and skeletal material was cleaned for further identification. These specimens were deposited into the USGS Biological Survey Collection at the Museum of Southwestern Biology, University of New Mexico.

\section{Results}

A total of 88 net-nights was amassed from 18 sites between March 29 and August 6 (table 1, fig. 1, appendix). Of the 18 sites visited, 12 yielded captures of 421 bats belonging to 8 species: 
C. townsendii, E. fuscus, M. ciliolabrum, M. evotis, M. thysanodes, M. volans, L. noctivagans, and $T$. brasiliensis (table 2). None of the captured bats showed any evidence for the presence of WNS or $G$. destructans. Of the 12 net locations, 5 had captures of greater than 30 bats per site for one night: Laguna de Juan Garcia (79 bats captured), Cerrito Comadre I (47), Bonita Canyon III (46), Cerro Rendija III (33), and Cerro Rendija V (31, table 1). However, summed counts from multiple dates of effort per site increased total capture numbers for some locations, including Laguna de Juan Garcia (155 bats), Cerro Rendija III (39), and Cerro Rendija V (35, table 3).

Table 1. Dates, level of net effort, and number of bats captured in mist nets at each net location during 2011 (See appendix for site description).

\begin{tabular}{|c|c|c|c|}
\hline Net location & Date & \# Nets used & \# Bats netted \\
\hline Cerro Americano & March 29, 2011 & 2 & 0 \\
\hline Bonita Canyon III & May 4, 2011 & 2 & 46 \\
\hline Cerro Americano & May 5, 2011 & 2 & 0 \\
\hline Cerrito Comadre II & May 17, 2011 & 2 & 0 \\
\hline Cerro Hueco I & May 18, 2011 & 1 & 0 \\
\hline Cerro Hueco II & June 6, 2011 & 2 & 5 \\
\hline Cerrito Comadre I & June 7, 2011 & 3 & 47 \\
\hline Cerro Rendija II & June 8, 2011 & 2 & 8 \\
\hline Braided Cave Tank & June 9, 2011 & 2 & 5 \\
\hline Cerro Rendija IV & June 10, 2011 & 4 & 13 \\
\hline Laguna de Juan Garcia & June 20, 2011 & 4 & 49 \\
\hline Prairie Dog Well I & June 21, 2011 & 3 & 26 \\
\hline Cerro Rendija III & June 22, 2011 & 3 & 33 \\
\hline Cerro Rendija V & June 23, 2011 & 4 & 31 \\
\hline Cerro Lobo I & June 24, 2011 & 3 & 18 \\
\hline Laguna de Juan Garcia & June 27, 2011 & 4 & 79 \\
\hline Cerro Rendija II & June 28, 2011 & 2 & 0 \\
\hline Cerro Hueco II & June 29, 2011 & 2 & 5 \\
\hline Braided Cave Tank & June 30, 2011 & 2 & 13 \\
\hline Cerro Lobo II & July 1, 2011 & 2 & 0 \\
\hline Laguna de Juan Garcia & July 25, 2011 & 4 & 10 \\
\hline Cerro Rendija III & July 26, 2011 & 3 & 6 \\
\hline Laguna Americana & July 27, 2011 & 4 & 0 \\
\hline Prairie Dog Well II & July 28, 2011 & 4 & 0 \\
\hline Cerro Rendija I & July 29, 2011 & 3 & 0 \\
\hline Cerro Rendija IV & August 1, 2011 & 4 & 1 \\
\hline Laguna de Juan Garcia & August 2, 2011 & 4 & 17 \\
\hline Cerrito Comadre I & August 3, 2011 & 4 & 0 \\
\hline Cerro Rendija V & August 4, 2011 & 4 & 4 \\
\hline Cerro Rendija I & August 5, 2011 & 3 & 5 \\
\hline Total & & 88 & 421 \\
\hline
\end{tabular}




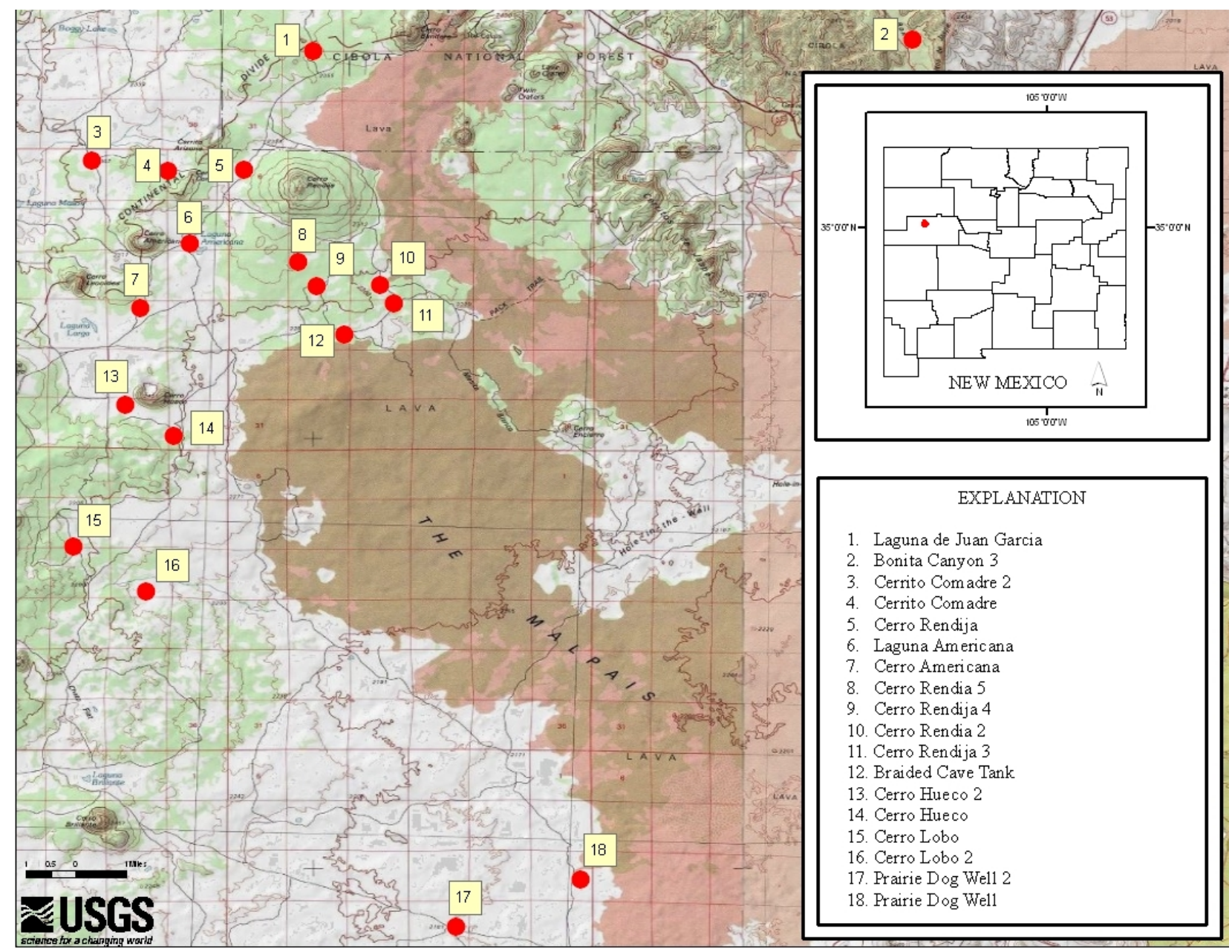

Figure 1. Map of sites netted for bats on ELMA and adjacent lands during 2011. Red dot on inserted map of New Mexico represents general location of ELMA, whereas numbered red dots on larger map represent specific sites netted on ELMA and adjacent lands (See appendix for coordinates, location description, and level of effort.) 
Table 2. Numbers of individuals and species netted at 12 of 18 sites sampled in 2011 (See appendix for level of effort at each site.)

\begin{tabular}{llccc} 
Scientific name & Common name & Male & Female & Total \\
\hline Myotis evotis & Long-eared Myotis & 195 & 6 & 201 \\
Myotis ciliolabrum & Small-footed Myotis & 93 & 1 & 94 \\
Myotis thysanodes & Fringed Myotis & 38 & 4 & 42 \\
Lasionycteris noctivagans & Silver-haired Bat & 37 & 3 & 40 \\
Eptesicus fuscus & Big Brown Bat & 25 & 3 & 28 \\
Myotis volans & Long-legged Myotis & 6 & & 6 \\
Corynorhinus townsendii & Townsend's Big-eared Bat & 3 & 2 & 5 \\
Tadarida brasiliensis & Brazilian free-tailed bat & 5 & & 5 \\
\hline Total & & 402 & 19 & 421 \\
\hline
\end{tabular}

Table 3. Numbers of individuals and species netted at 12 of 18 sites sampled in 2011 (See appendix for level of effort at each site.)

\begin{tabular}{lcc}
\hline \multicolumn{1}{c}{ Locality } & $\begin{array}{c}\text { Total number of } \\
\text { individuals }\end{array}$ & $\begin{array}{c}\text { Number of species } \\
\text { represented }\end{array}$ \\
\hline Bonita Canyon III & 46 & 3 \\
Braided Cave Tank & 18 & 4 \\
Cerrito Comadre I & 47 & 5 \\
Cerro Hueco II & 10 & 3 \\
Cerro Lobo I & 18 & 3 \\
Cerro Rendija I & 5 & 3 \\
Cerro Rendija II & 8 & 3 \\
Cerro Rendija III & 39 & 3 \\
Cerro Rendija IV & 14 & 2 \\
Cerro Rendija V & 35 & 7 \\
Laguna de Juan Garcia & 155 & 8 \\
South of Prairie Dog Well I & 26 & 5 \\
\hline
\end{tabular}


The overall number of species captured at each location ranged from 2 to 8, with Laguna de Juan Garcia and Cerro Rendija V having the greatest diversity of 8 and 7 species, respectively (table 3 ). The three most frequently encountered species during 2011 were M. evotis, M. ciliolabrum, and $M$. thysanodes. Of these species, M. evotis was the most abundant, with 201 individuals captured across all 12 sites (except Bonita Canyon III and Prairie Dog Well I) that had netted individuals (tables 2 and 3). Myotis ciliolabrum was the second most abundant bat netted, with 94 individuals captured at all sites, except Cerro Rendija II and Cerro Rendija IV (tables 2 and 3). Finally, 42 M. thysanodes were captured at all sites, except Bonita Canyon III and Cerrito Comadre I, that had netted individuals (tables 2 and 3). Forty L. noctivagans were captured prior to June 27, but not after this date. Although there were no captures, a single E. maculatum was heard producing its distinct audible calls while flying over Laguna de Juan Garcia on July 25.

Throughout this study, males were more common at all sites, with 402 individuals netted compared to the 19 females (table 2). For species with captures of both sexes, the proportions of males to females were greatest for M. ciliolabrum (93:1) and M. evotis (33:1, table 2). The M:F sex ratio for $C$. townsendii was near equal at 1.5:1; however, this likely reflects the small sample size of 5 individuals (table 2). No males showed noticeable signs of reproductive condition (that is, enlarged testes or epididymides); however, 5 females captured between 20 June and 2 August were pregnant, lactating, or post-lactating. These included 1 pregnant $C$. townsendii; 1 pregnant $M$. thysanodes; 1 lactating $M$. evotis; and 1 lactating and 1 post-lactating E. fuscus. No volant young were netted during 2011.

Laguna de Juan Garcia was the only site that was visited four times (June 20 and 27, July 25, and August 2) during the last date of spring and throughout summer of 2011. Bats netted at Laguna de Juan Garcia were captured using the same number, sizes, and placement of nets along the bank and edge of the water (appendix). On June 20, 49 bats belonging to 8 species were captured (table 4). Of these, $M$. evotis and M. ciliolabrum comprised most of the captures with 26 and 11 individuals, respectively (table 4). All bats captured were male, except for a single female $C$. townsendii. On June 27, the number of captures increased noticeably with a total of 79 bats netted, representing 7 species (table 4 ). Of these, $M$. evotis, M. ciliolabrum, and M. thysanodes represented captures greater than 10 with 37, 20, and 11 bats netted respectively (table 4). All 79 bats netted on June 27 were males. On July 25, 10 bats were netted belonging to 4 species. Like the previous dates at Laguna de Juan Garcia, net captures were dominated by M. evotis, with four individuals netted (table 4). However, T. brasiliensis was the second-most abundant species with 3 individuals netted, whereas E. fuscus and M. ciliolabrum were represented by 2 individuals and 1 individual, respectively. All captures on July 25 were males, except for a single $E$. fuscus. On August 2, the final net date at Laguna de Juan Garcia, 17 bats of 5 species were netted (table 4). Of these species, M. evotis dominated the total number of captures with 9 bats netted, followed by M. thysanodes (4 bats), M. ciliolabrum (2), M. volans (1), and E. fuscus (1, table 4). All individuals netted on 2 August were males except for a single E. fuscus. From all net efforts at Laguna de Juan Garcia, a single C. townsendii netted on June 20 and two E. fuscus netted on July 25 and August 2 were the only females captured that showed signs of being pregnant, lactating, and post-lactating, respectively.

Although voucher specimens were collected in 1999 and 2000 from lands adjacent to ELMA, none came directly from the park during that time. Because Laguna de Juan Garcia was an important study site in 2011 and the only known open-water source on the park, it was important to keep a select few individuals from that site. Vouchers retained included: 1 male M. ciliolabrum, 2 male M. evotis, 2 male $M$. thysanodes, 1 male $M$. volans, and 1 female $E$. fuscus. These served as reference specimens for all identifications of those species captured during 2011. 
Table 4. Dates, species, counts, and sexes of bats netted at Laguna de Juan Garcia during 2011.

\begin{tabular}{|c|c|c|c|c|}
\hline Date & Species & Male & Female & Total \\
\hline \multirow[t]{8}{*}{ June 20, 2011} & Corynorhinus townsendii & & 1 & 1 \\
\hline & Eptesicus fuscus & 2 & & 2 \\
\hline & Lasionycteris noctivagans & 6 & & 6 \\
\hline & Myotis ciliolabrum & 11 & & 11 \\
\hline & Myotis evotis & 26 & & 26 \\
\hline & Myotis thysanodes & 1 & & 1 \\
\hline & Myotis volans & 1 & & 1 \\
\hline & Tadarida brasiliensis & 1 & & 1 \\
\hline Subtotal & & 48 & 1 & 49 \\
\hline \multirow[t]{7}{*}{ June 27, 2011} & Corynorhinus townsendii & 1 & & 1 \\
\hline & Eptesicus fuscus & 3 & & 3 \\
\hline & Lasionycteris noctivagans & 6 & & 6 \\
\hline & Myotis ciliolabrum & 20 & & 20 \\
\hline & Myotis evotis & 37 & & 37 \\
\hline & Myotis thysanodes & 11 & & 11 \\
\hline & Myotis volans & 1 & & 1 \\
\hline Subtotal & & 79 & & 79 \\
\hline \multirow[t]{4}{*}{ July 25, 2011} & Eptesicus fuscus & 1 & 1 & 2 \\
\hline & Myotis ciliolabrum & 1 & & 1 \\
\hline & Myotis evotis & 4 & & 4 \\
\hline & Tadarida brasiliensis & 3 & & 3 \\
\hline Subtotal & & 9 & 1 & 10 \\
\hline \multirow[t]{5}{*}{ August 2, 2011} & Eptesicus fuscus & & 1 & 1 \\
\hline & Myotis ciliolabrum & 2 & & 2 \\
\hline & Myotis evotis & 9 & & 9 \\
\hline & Myotis thysanodes & 4 & & 4 \\
\hline & Myotis volans & 1 & & 1 \\
\hline Subtotal & & 16 & 1 & 17 \\
\hline Total & & 152 & 3 & 155 \\
\hline
\end{tabular}




\section{Discussion}

During this study, I did not encounter any evidence from the mist-netting of bats to suggest that white-nose syndrome or G. destructans are present at ELMA, but it is possible that the subtle signs of some infections may not have been observed. Given that the distance from the nearest record of $G$. destructans in Oklahoma is approximately $500 \mathrm{mi}(805 \mathrm{~km})$ and the distance from the nearest record of confirmed WNS in Kentucky/Tennessee is approximately 1,124 $\mathrm{mi}(1,809 \mathrm{~km})$, the likelihood that the causal agent or disease was present at ELMA during 2011 seemed to be low. According to Lorch and others (2011), this disease is mainly transmitted from bat to bat by direct contact, usually by individuals from the same infected hibernaculum. This allows for rapid spread of the disease as infected individuals move among sites.

In addition to the findings by Lorch and others (2011), and according to U.S. Fish and Wildlife Service (2011), G. destructans is regarded as an infectious agent with spores that can be potentially spread by a variety of modes of disease transmission, including fomites. Because there is easy access to lava-tube caves by the general public, it is possible that spores can be transmitted by people from infected areas to lava-tube caves at ELMA that serve as hibernacula. However, despite the potential for G. destructans to arrive at ELMA, it is currently unknown whether lava-tube habitats and microclimates are suitable to sustain this species of fungus.

During my inspection of bats for WNS, I observed wing scarring on a few individuals, but unlike the scarring of WNS-affected bats as described by Reichard and Kunz (2009). Although wing scarring has been associated with WNS (Reichard and Kunz, 2009), often these anomalies are not attributed to the disease. Instead, wing scarring is relatively common in species that are known to fly around vegetation and glean insect prey from the ground or plant surfaces, such as M. evotis (Manning and Jones, 1989). During a 5-year capture-recapture rabies study on E. fuscus, Ellison and others (written commun., April 1, 2011) documented multiple bats that had scarring, tears, or holes in their wing membranes. They concluded that wing scarring in E. fuscus is a common component of healthy populations and can be caused by a variety of factors (for example, bites from individuals sharing a roost, puncture wounds from twigs on trees) - a phenomenon that they suggested future WNS studies should take into account.

Myotis evotis and M. ciliolabrum were the most commonly encountered species at ELMA and on adjacent lands. Given the occurrence and number of individuals netted near the known lava-tubes, it is likely that both of these species use the lava-tubes as hibernacula. Both species share similar morphology, taxonomic relationships, and life histories to congeners, M. evotis with M. septentrionalis (Northern Long-eared Myotis; see Whitaker and Rissler, 1992; Faure and others, 1993; Van Zyll de Jong and Nagorsen, 1994), and M. ciliolabrum with M. leibii (Eastern Small-footed Myotis; see Best and Jennings, 1997; Rodriguez and Ammerman, 2004). Both M. septentrionalis and M. leibii occur in the eastern United States and are currently affected by WNS. It is thus possible that M. evotis and $M$. ciliolabrum may be as susceptible to WNS infection, along with other species of Myotis that occur in the Southwest.

\section{Net Captures}

In general, the 421 bats captured with an effort of 88 net-nights (or about 5 bats/net-night) was similar to the 232 bats with 30 net-night effort ( 8 bats/net-night) captured in 1999 and 324 bats with 56 net-nights ( 6 bats/net-night) netted in 2000, as reported by Valdez and others (2002). Although the number of bats per net-night was greater for 1999 and 2000 when compared to this study, the numbers of sites sampled during those years were fewer, at 10 and 12 sites, respectively. The fewer captures in 
2011 mostly reflect the concentrated effort during spring; a time when fewer bats were flying likely due to cold temperatures and high wind speeds. For example, in a direct comparison of wind speeds for 2011, 2000, and 1999, the average wind speeds between March 1 and May 30 of those years were 10.3, 2.2, and 2.7 miles per hour $(\mathrm{mph})(16.5,3.5$.and 4.3 kilometers per hour $(\mathrm{kmph})$ ), respectively, with peak wind gusts of $32 \mathrm{mph}(51.5 \mathrm{kmph})$ reported for 2011; a wind speed twice as great as the fastest wind gusts for 2000 and 1999 (fig. 2).

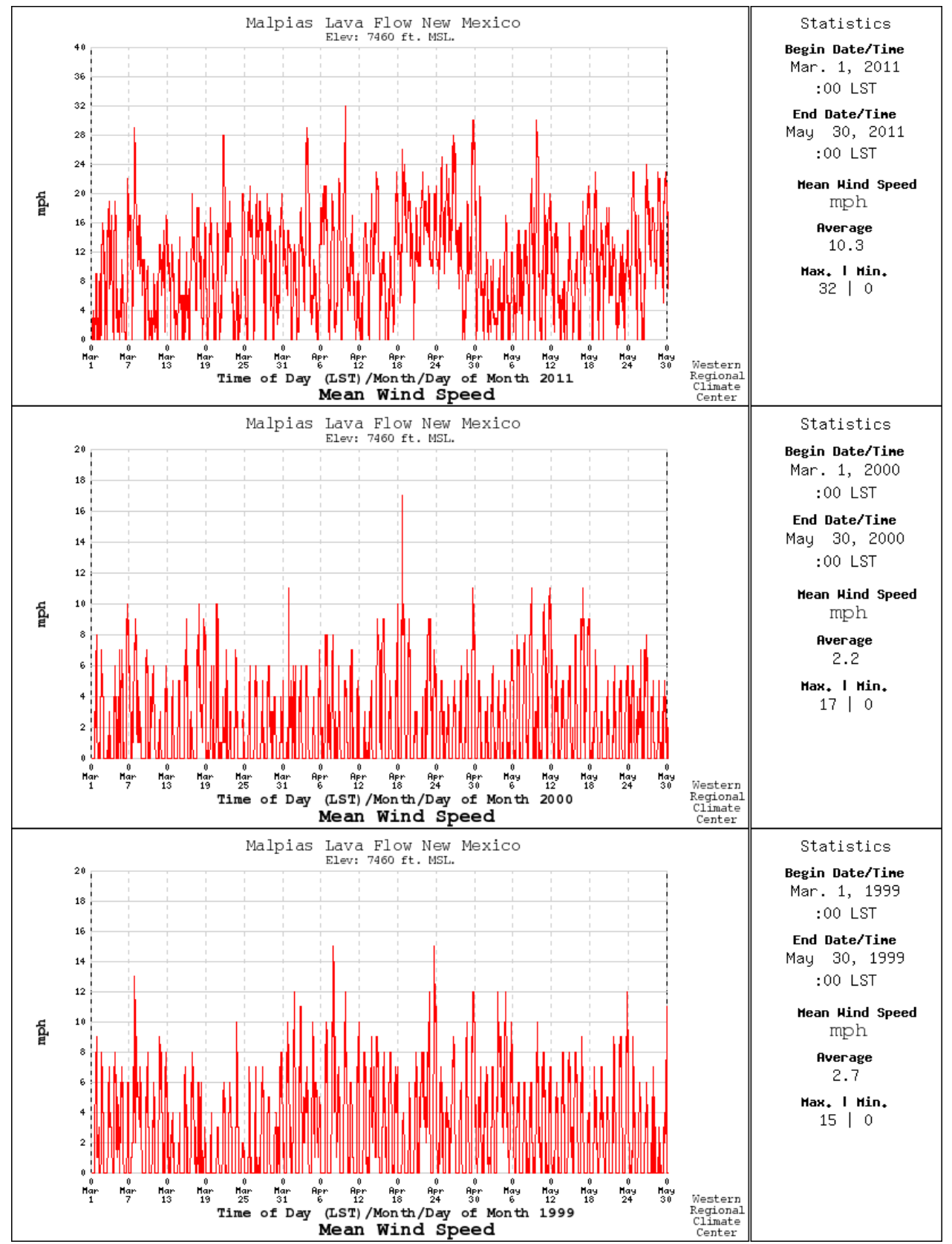

Figure 2. Wind speeds recorded between March 1 and May 30, 2011, 2000, and 1999 at El Malpais National Monument. Wind speed data of sites netted on ELMA and adjacent lands during 2011 obtained from Western Regional Climate Center (2011). 
During this study, 8 species of bats were captured, whereas 12 species were netted in both 1999 and 2002 by Valdez and others (2002). This decrease in the number of species encountered in 2011 partly reflects the locations netted and the uncommon species captured by Valdez and others (2002). For example, A. pallidus was only netted on BLM land near southern boundary of ELMA; an area that was not extensively sampled in 2011. Also, the absence of $L$. cinereus from the net captures in 2011 likely indicates that it is a species that is not common at ELMA, as shown by capture results by Valdez and others (2002) and Geluso and Bogan (2005). This paucity in occurrence is likely attributed to this species' seasonal presence as it migrates through the state. It is possible that the main migratory pathways of L. cinereus do not include ELMA (Cryan, 2003).

\section{Skewed Sex Ratios}

One of the more interesting findings from this study was the skewed sex ratios for many of the species encountered, with an overall 402 males and 19 females captured. Although all species captured during this study included more males than females, M. ciliolabrum and M. evotis had the greatest M:F ratios when both sexes where captured. This trend was also documented for most of the species captured at ELMA in 1999 (that is, 199 males and 33 females captured) and 2000 (that is, 283 males and 39 females captured) by Valdez and others (2002). However, in 1999, the sex ratios for M. ciliolabrum and M. evotis were 4.2:1 and 7.8:1, respectively, whereas in 2000 they were 19.3:1 and 59:1, respectively (Valdez and others, 2002).

The phenomenon of skewed sex ratios has been documented by Cryan and others (2000) for $M$. ciliolabrum, M. septentrionalis, $M$. thysanodes, M. volans, L. cinereus, L. noctivagans, and E. fuscus occurring in the Black Hills of South Dakota. In this region, males have been reported from elevations near 1,500 $\mathrm{m}$ and higher and reproductive females have been reported at approximately 1,400 $\mathrm{m}$ and lower. Cryan and others (2000) noted that although females may be sharing the same hibernacula sites at higher elevations with males during winter, females would migrate to lower elevations where drier climate and warmer temperatures would contribute to greater thermoregulatory and foraging opportunities, especially when compensating for spring and summer reproductive conditions. Cryan and others (2000) also noted that these trends continued throughout the summer after females gave birth. The trends also applied to volant young.

Interestingly, the few (that is, less than 10) reproductive females documented in this study is only consistent with the findings by Valdez and others (2002) for 1999, compared to the 30 individuals noted as being pregnant, lactating, or post-lactating that were captured during 2000. Many of the reproductive females captured by Valdez and others (2002), during both years, were from lower elevations near the southern end of ELMA; this is a location that was not netted frequently in 2011. I suspect that the overall greater prevalence of males encountered at ELMA and adjacent lands during 2011, compared to the low number of reproductive females and absence of volant young, reflects similar conditions observed by Cryan and others (2000). However, elevation boundaries between sexes may fluctuate according to climatic conditions or some unknown factor encountered over time, as documented in 2000 by Valdez and others (2002).

\section{Laguna de Juan Garcia}

To date, Laguna de Juan Garcia appears to be the only site at ELMA that is used heavily by bats for drinking and possibly foraging. This site may be especially important during periods of drought when other water sources are not available. One key feature of Laguna de Juan Garcia is the overall size of unobstructed water surface. The long and wide pool allows all bat species that are likely to occur at ELMA to use this water source, including less-maneuverable species such as $T$. brasiliensis and $N$. 
macrotis. Of all sites netted during 2011, Laguna de Juan Garcia had the greatest number of captures and species diversity for one night. This site was also the only location where E. maculatum was heard flying overhead in 2011.

Because unobstructed water surfaces are important for bats to drink from, it is critical that this water resource is managed as a drinking resource for bats. Management of sites like Laguna de Juan Garcia and other earthen ponds should include removing debris and invasive plants that would obscure the open surface of the water. Water impoundments that are filled by seasonal precipitation should be managed to allow for maximum catchment of water. Not only is the water source of Laguna de Juan Garcia important to bats, but the surrounding forest habitat is equally important. The ponderosa pine forest likely provides foraging areas used by $M$. evotis and other species of bats that are capable of maneuvering through vegetation clutter. Also, many species of bats are likely using trees, particularly snags, cavities in trees, and exfoliating bark, as roosts sites (Chung-MacCoubrey, 2005; Bogan and others, 1998).

Overall, the peak number of captures during this study coincided with trends in the climatic conditions (for example, temperature and availability of water) at ELMA. This was particularly noticeable in the number of captures recorded over June 20 and 27, July 25, and August 2 at Laguna de Juan Garcia. For example, the increase of 49 to 79 bats recorded on June 20 and 27, respectively, is indicative of seasonal peak occurrence that generally coincides with warmer temperatures, but the peak appears to be more prominent with the limited availability of water sources. This is noticeable in the less than 0.5 inch (in) $(1.27 \mathrm{~cm})$ of precipitation recorded during June 20 and 27 (fig. 3). The decline in captures to 10 and 17 individuals recorded on July 25 and August 2, respectively, reflect the availability of additional water resources as a result of seasonal monsoon rains as noted in the greater than 2 in (approximately $5 \mathrm{~cm}$ ) of rain recorded on July 25 and August 2, 2011 (fig. 3). Such seasonal weather and patterns of bat occurrence are not uncommon in the Southwest (Geluso and Geluso, 2012). However, the availability of permanent water sources (that is, Laguna de Juan Garcia), especially during periods of drought, is critical to bats when resources are limited.

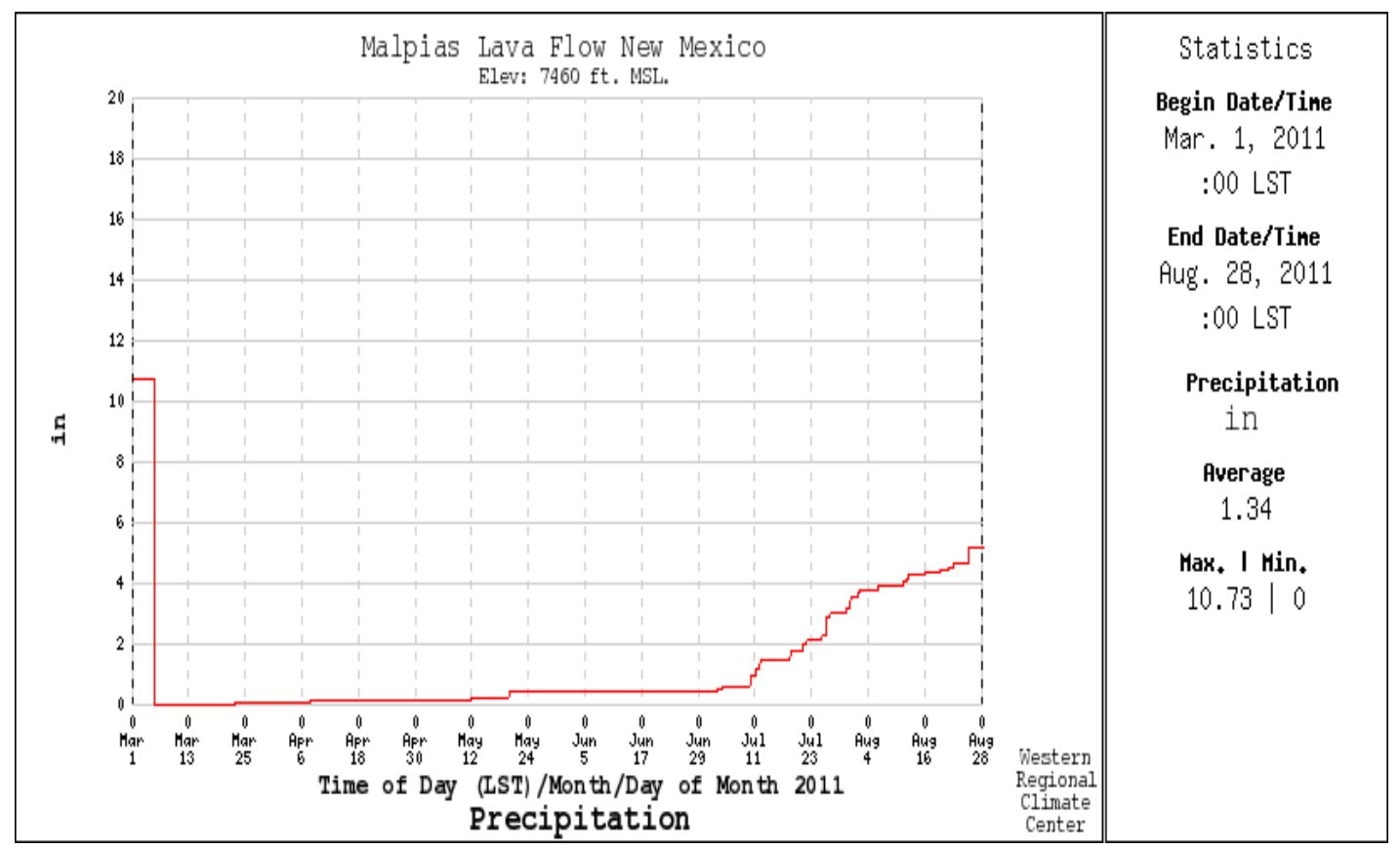

Figure 3. Amount of precipitation (inches) recorded at El Malpais National Monument between March 1 and August 28, 2011. Precipitation data obtained from Western Regional Climate Center (2011). 


\section{Effects of Wildfires on Bats and Potential Impacts to Laguna de Juan Garcia}

During 2011, extreme drought conditions in the Southwest coincided with the occurrence of several wildfires, including the Wallow Fire near the west-central border of New Mexico and Arizona. This fire started during May, 2011, by June had burned over 500,000 acres of forest in Arizona and parts of New Mexico, and at its closest was approximately $100 \mathrm{mi}(161 \mathrm{~km})$ from ELMA. Prior to containment and during our efforts at ELMA in May and June, smoke from the Wallow Fire was at times dense with visibility limited to $1-2 \mathrm{mi}$ (approximately $2-3 \mathrm{~km}$ ). Although the local weather conditions were adequate for netting, it was unknown if the dense smoke would have an impact on bats. Surprisingly, the number of captures at net sites across ELMA and adjacent lands during this period (for example, June 7-30) of dense smoke were equal to, and at times greater than, the captures at the same sites when smoke was not present, thus suggesting that the smoke from the Wallow Fire did not have a negative effect on bats at ELMA. This was particularly noticeable with the increase of 49 to 79 bats captured at Laguna de Juan Garcia on the respective dates of June 20 and 27. However, this spike in number should not be regarded as a positive effect of smoke on bat captures, but instead a result of the seasonal abundance and availability of water during this study.

It is likely that direct contact of smoke and fire from a large-scale fire, such as the Wallow Fire, on ELMA or adjacent lands will have a negative impact on the forest, woodland, and grassland habitats that are used by bats as foraging areas and roosting habitats, especially if fuel sources are high during drought conditions. Furthermore, large fires that could occur on the park may also cause the loss of water resources, such as Laguna de Juan Garcia, through sediment fill-in of earthen ponds after fires have scorched ground vegetation, as observed by O'Shea and others (2011) at Mesa Verde National Park. Given the La Niña conditions of 2011 and similar patterns predicted for 2012, fire-management tools should be taken into consideration when managing the surrounding areas of known water, foraging, and roost resources at ELMA.

\section{Overview of Bats at ELMA and Adjacent Lands and Some Recommendations}

In 2011, twelve species of bat were confirmed to occur on ELMA and from adjacent lands that were surveyed. Confirmation of these species was based on the results from this study compared with voucher specimens of 10 species collected from ELMA and adjacent lands; records of distinct audible calls and simultaneous observations of bats flying overhead; distribution maps by Findley and others (1975); and a review of data by Lightfoot and others (1994), Valdez and others (2002), Geluso and Bogan (2005), and Wynne (2011). Of these twelve species, A. pallidus, C. townsendii, E. fuscus, L. noctivagans, L. cinereus, M. ciliolabrum, M. evotis, M. thysanodes, M. volans, and T. brasiliensis are represented by net captures and voucher specimens, whereas $N$. macrotis, and E. maculatum are documented by their distinct audible and ultrasonic calls, as well as observed flight activity. Most of these species are residents of the area, except for L. cinereus, T. brasiliensis, N. macrotis, and possibly L. noctivagans, which all are known to migrate during the spring and autumn seasons (Barbour and Davis, 1969).

Although there have been previous reports of other bat species occurring on ELMA and from adjacent lands, many of these represent misidentified bats, and in some instances, are unlikely to occur at ELMA or have not been confirmed. For example, Lightfoot and others (1994; p. 483, Off-Site Record Number OS-54), netted 3 M. velifer (Cave Myotis) near the western boundary of ELMA, approximately $1.90 \mathrm{mi}(3.2 \mathrm{~km})$ from the Cerro Lobo II site of this study. In addition, Lightfoot and others (1994, p. 60) observed several skeletons of $M$. velifer on the floor of Four Windows Cave and suspected that this species uses this site as a roost. Unfortunately, no specimens from their study were taken to verify identification. Regardless, it is unlikely that these individuals were $M$. velifer. This species is a desert- 
dwelling bat and within New Mexico is only known from the extreme southwestern and southeastern corners of the state (Findley and others, 1975).

Lightfoot and others (1994), Valdez and others (2002) and Geluso and Bogan (2005) report the presence of $M$. californicus. After re-examination of the voucher representatives of $M$. californicus taken by Valdez and others (2002), that were also used by Geluso and Bogan (2005) as a guide for identification in their study, these records have been determined to be M. ciliolabrum: a species that can be difficult to distinguish from M. californicus in the field. Although Valdez and others (2002) recorded echolocation call signatures of $M$. californicus, as well as for M. yumanensis and $P$. hesperus, the reliability of species identifications, especially for Myotis, can be questionable without having specimen vouchers to validate its presence. At present, no voucher evidence documenting the presence of $M$. californicus, M. yumanensis, or P. hesperus at ELMA exists. Despite this, it is possible that $M$. californicus, M. yumanensis, and P. hesperus occur in ELMA, but likely in small numbers. Based on distribution maps by Findley and others (1975), I suspect that M. californicus, M. yumanensis, and $P$. hesperus would likely be encountered near the southern and eastern areas of ELMA.

The presence of $M$. auriculus at ELMA, as reported by Valdez and others (2002), has come into question. Similar to the difficulties in field identifications between M. californicus and M. ciliolabrum, $M$. auriculus can be confused with $M$. evotis. Recent examinations of voucher specimens by Geluso and Bogan (2005) showed that specimens collected by Valdez and others (2002) were actually M. evotis. This confusion was attributed to the brown ears, atypical of $M$. evotis but apparent in some individuals at ELMA, as observed in the voucher specimen collected by Valdez and others (2002) and captures of individuals during this study. Although there are no confirmed records of M. auriculus at ELMA, it is possible that this bat can be found outside of its known range, such as the range-extension record from Harding County, N. Mex. as documented by Geluso (2002). The possible occurrence of M. auriculus at ELMA could be in habitat similar to that used by M. evotis, where both species have been known to cooccur (see Husar, 1976).

Although Myotis occultus (Occult Myotis or Arizona Myotis), formerly regarded as a subspecies of M. lucifugus (Little Brown Bat; see Piaggio and others, 2002), has been reported from neighboring areas such as El Morro National Monument and the Zuni Mountains (Bogan and others, 2007; Valdez and others, 1999), it is absent from the areas sampled at ELMA and adjacent lands. It is likely that this species prefers montane habitat at higher elevations and is excluded from the habitat at ELMA and adjacent lands by competing species during the summer, but it may be present on ELMA during the winter by using lava-tubes as hibernacula.

Overall, the assemblage of bat species at ELMA and adjacent areas is similar to other national parks and monuments, such as Mesa Verde National Park (O'Shea and others, 2011) and El Morro National Monument (Bogan and others, 2007), that also have piñon-juniper woodlands and scattered ponderosa pine forests with limited water resources nearby. However, the unique geologic features of lava flows and associated lava-tubes that provide roost habitat, particularly hibernacula, distinguish ELMA from these other parks. The combination of critical roost habitat provided by lava-tubes, limited water resources, and foraging areas used by bats at ELMA deserves special attention in addressing potential negative effects on bats from WNS and other factors (for example, fire, or drought).

Some recommendations to consider for future management and research include the following:

1. Locate new or unknown sites that are used as hibernacula by bats at ELMA.

2. Continue surveillance for G. destructans and WNS above and below ground.

3. Investigate subterranean habitat and related micro-climate to provide better understanding of and possible comparisons on the likelihood of WNS in the Southwest. 
4. Mitigate for impacts to bats from human disturbance at known hibernacula and other critical bat habitat.

5. Investigate above-ground roosts that could serve as potential contact zones between bats and spores of $G$. destructans during summer months.

6. Manage water impoundments (for example, Laguna de Juan Garcia) as important water sources for bats by keeping water surfaces free of debris and invasive plants and ensuring maximum catchment of seasonal precipitation.

7. Provide fire management tools and strategies to protect surrounding areas of known water, foraging, and roost resources of ELMA bats.

8. Investigate the ecological impacts of bats as major insect predators and possible effects on local habitat (for example, change in micro-climate of lava-tubes from loss of forest cover related to insect infestations) from population losses as a result of WNS.

Addressing these recommendations will provide a greater level of preparedness in the event of a biological crisis, such as WNS, with information that can aide in habitat and wildlife management decisions made by ELMA. Furthermore, addressing these recommendations provides new insight into the poorly known natural history information of bats at ELMA and adjacent lands, as well as for the Southwest.

\section{Acknowledgments}

I thank B. Holden, D. Dombrowski, D. Sullivan, R. Bastik, M. Ireland, and D. Hays of the National Park Service for their logistical support during this study. I thank A. Chavez and B. DeGruyter and their respective BLM and USFS agencies for their logistical support to work on their landmanagement areas. I thank K. Hall, D. Hall, and J. Porter for their assistance and insight on locations of available net sites. I extend a special thanks to T.J. O'Shea, R. Bastik, and C.W. Valdez for their assistance in the field. Thanks to C.A. Ramotnik and the USGS Biological Survey Collection at the Museum of Southwestern Biology, University of New Mexico for museum support. I thank K. Geluso, M.A. Bogan, and F.P. Cryan for their insight on the occurrence of bats at ELMA and adjacent areas, as well as their comments on an earlier draft of this report.

\section{References Cited}

Barbour, R.W., and Davis, W.H., 1969, Bats of America: Lexington, Kentucky, The University Press of Kentucky, $286 \mathrm{p}$.

Best, T.L., and Jennings, J.B., 1997, Myotis leibii: Mammalian species, v. 547, p. 1-6.

Bogan, M.A., Geluso, K., Haymond, S., and Valdez, E.W., 2007, Mammal inventories for eight national parks in the Southern Colorado Plateau Network-Aztec Ruins National Monument, Bandelier National Monument, Chaco Culture National Historical Park, El Malpaís National Monument, El Morro National Monument, Petroglyph National Monument, Salinas Pueblo Missions National Monument, Yucca House National Monument: Washington D.C., National Park Service, Natural Resource Technical Report NPS/IMR/SCPN/NRTR-2007/054, 118 p.

Bogan, M.A., O’Shea, T.J., Cryan, P.M., Ditto, A.M., Shaedla, W.H., Valdez, E.W. , and Castle, K.T., 1998, A study of bat populations at Los Alamos National Laboratory and Bandelier National Monument, Jemez Mountains, New Mexico: Los Alamos National Laboratory, LA-UR-98-2418. 
Brunet-Rossinni, A.K., and Wilkinson, G.S., 2009, Age estimation and senescence, in Kunz, T.H. and Parsons, S., eds, Ecological and behavioral methods for the study of bats ( $2 \mathrm{~d}$ ed.): Baltimore, Md., The Johns Hopkins University Press, p. 315-325.

Boyles, J.G., Cryan, P.M., McCracken, G.F., and Kunz, T.H., 2011, Economic importance of bats in agriculture: Science, v. 332, p. 41-42.

Chung-MacCoubrey, A.L., 2005, Use of pinyon-juniper woodlands by bats in New Mexico: Forest Ecology and Management, v. 204, p. 209-220.

Cryan, P.M., Bogan, M.A., Altenbach, J.S., 2000, Effect of elevation on distribution of female bats in the Black Hills, South Dakota: Journal of Mammalogy, v. 81, p. 719-725.

Cryan, P.M., 2003, Seasonal distribution of migratory tree bats (Lasiurus and Lasionycteris) in North America: Journal of Mammalogy, v. 84, p. 579-593.

Faure, P.A., Fullard, J.H., and Dawson, J.W., 1993, The gleaning attacks of the northern long-eared bat, Myotis septentrionalis, are relatively inaudible to moths: Journal of Experimental Biology, v. 178, p 173-189.

Findley, J.S., Harris, A.H., Wilson, D.E., Jones, C., 1975, Mammals of New Mexico: Albuquerque, NM, University of New Mexico Press, 360 p.

Frey, J.K., 2004, Taxonomy and distribution of the mammals of New Mexico-An annotated checklist: Occasional Papers, Museum of Texas Tech University, p. 240, p. 1-32.

Gargas, A., Trest, M.T., Christensen, M., Volk, T.J., and Blehert, D.S., 2009, Geomyces destructans sp. Nov. associated with bat white-nose syndrome: Mycotaxon, v. 108, p. 147-154.

Geluso, K., 2002, Records of mammals from Harding County, New Mexico: The Southwestern Naturalist, v. 47, p. 325-329.

Geluso, K., 2007, Winter activity of bats over water and along flyways in New Mexico: The Southwestern Naturalist, v. 54, p. 482-492.

Geluso, K., and Bogan, M.A., 2005, Final Report-2003-2004 Mammalian Inventories for three national Parks in the Southern Colorado Plateau Network-Bandelier National Monument, Chaco Culture National Historic Park, and El Malpais National Monument: U.S. Geological Survey, 78 p.

Geluso, K.N., and Geluso, K., 2012, Effects of environmental factors on yearly fluctuations in capture rates of insectivorous bats, 1971-2005: Journal of Mammalogy, v. 93, p. 161-169.

Hall, E.R., 1981, The Mammals of North America, (2d ed.): Caldwell, NJ, The Blackburn Press, v. 1, 600 p. +90.

Hecker, K.R., and Brigham, R.M., 1999, Does moonlight change vertical stratification of activity by forest-dwelling insectivorous bats?: Journal of Mammalogy, v. 80, p. 1196-1201.

Husar, S.L., 1976, Behavioral character displacement-Evidence for food partitioning in insectivorous bats: Journal of Mammalogy, v. 57, p. 331-338.

Kunz, T.H., Hodgkison, R., and Weise, C.D., 2009, Methods of capturing and handling bats, in Kunz, T.H., and Parsons, S., eds., Ecological and behavioral methods for the study of bats $(2 \mathrm{~d}$ ed.):

Baltimore, Md., The Johns Hopkins University Press, p. 3-35.

Lightfoot, D.C., Bleakly, D.L., Parmenter, R.R., and Gosz, J.R., 1994, Vegetation and wildlife inventory of El Malpais National Monument, final report: U.S. National Park Service, El Malapais National Monument. Grants, NM: Albuquerque, NM, University of New Mexico, 496 p.

Lorch, J.M., Meteyer, C.U., Behr, M.J., Boyles, J.G., Cryan, P.M., Hicks, A.C., Ballmann, A.E., Coleman, J.T.H., Redell, D.N., Reeder, D.M., and Blehert, D.S., 2011, Experimental infection of bats with Geomyces destructans causes white-nose syndrome: Nature, v. 480, p. 376-378.

Manning, R.W., and Jones, J.K., Jr., 1989, Myotis evotis: Mammalian Species, v. 329, p. 1-5. 
O’Shea, T.J., Cryan, P.M., Snider, E.A., Valdez, E.W., Ellison, L.E., and Neubaum, D.J., 2011, Bats of Mesa Verde National Park, Colorado - Composition, reproduction, and roosting habits: Monographs of the Western North American Naturalist, v. 5, p. 1-19.

Piaggio, A.J., Valdez, E.W., Bogan, M.A., and Spicer, G.S., 2002, Systematics of Myotis occultus (Chiroptera-Vespertilionidae) inferred from sequences of two mitochondrial genes: Journal of Mammalogy, v. 83, p. 386-395.

Reith, C.C., 1982, Insectivorous bats fly in shadow to avoid moonlight: Journal of Mammalogy, v. 63, p. 685-688.

Reichard, J.D., and Kunz, T.H., 2009, White-nose syndrome inflicts lasting injuries to the wings of little brown myotis (Myotis lucifugus): Acta Chiropterologica, v. 11, p. 457-464.

Rodriquez, R.M., and Ammerman, L.K., 2004, Mitochondrial DNA divergence does not reflect morphological difference between Myotis californicus and Myotis ciliolabrum: Journal of Mammalogy, v. 85, p. 842-851.

Sparks, D.W., and Choate, J.R., 2000, Distribution, natural history, conservation status and biogeography of bats in Kansas, in Choate, J.R. ed., Reflections of a naturalist_-Papers honoring Professor Eugene D. Fleharty: Hays, Kans., Fort Hays State University, Fort Hays Studies, Special Issue 1, p. 173-228.

U.S. Fish and Wildlife Service, 2009, White nose syndrome in bats, Frequently Asked Questions: Washington D.C., U.S. Fish and Wildlife Service, p. 1-2, accessed April 1, 2011, at http://www.fws.gov/northeast/pdf/white-nosefaqs.pdf

U.S. Fish and Wildlife Service, 2011, A national plan for assisting states, federal agencies, and tribes in managing white-nose syndrome in bats: Washington D.C., U.S. Fish and Wildlife Service, p. 1-21, accessed April 1, 2011, at http://www.fws.gov/WhiteNoseSyndrome/pdf/WNSnationalplanMay2011.pdf

U.S. Geological Survey, 2011, Wildlife Health Bulletin 2011-05, p. 1-2, accessed December 30, 2011 , at www.nwhc.usgs.gov/publications/wildlife_health_bulletins/WHB_2011-

05_UniversalPrecautions.pdf

Valdez, E.W., Choate, J.R., Bogan, M.A., and Yates, T.L., 1999, Taxonomic status of Myotis occultus: Journal of Mammalogy, v. 80, p. 545-552.

Valdez, E.W., Bogan, M.A., Ellison, L., and Haymond, S., 2002, Bat survey of El Malpais National Monument and adjacent areas, New Mexico, 1999 and 2000: Final Report to National Park Service: Fort Collins, Colorado, U.S. Geological Survey, Fort Collins Science Center, 59 p.

Van Zyll de Jong, C.G., and Nagorsen, D.W., 1994, A review of the distribution and taxonomy of Myotis keenii and Myotis evotis in British Columbia and the adjacent United States: Canadian Journal of Zoology, v. 72, p 1069-1078.

Western Regional Climate Center, 2011, RAWS USA Climate Archive: Reno Nevada, Western Regional Climate Center, Desert Research Institute, accessed December 30, 2011, at http://www.raws.dri.edu

Whitaker, J.O., Jr., and Rissler, L.J., 1992, Seasonal activity of bats at Copperhead Cave: Proceedings of the Indiana Academy of Science, v. 101, p. 127-135.

Wynne, J., 2011, Ecological inventory of lava-tube caves, El Malpais National Monument, New Mexico, final report 2011: Final Report to National Park Service: Flagstaff, Arizona, Colorado Plateau Research Station, Northern Arizona University, 18 p. 


\section{Appendix}

Descriptions of net sites sampled during 2011. Lat/Long coordinates taken by Global Positioning System are set to WGS84 Datum.

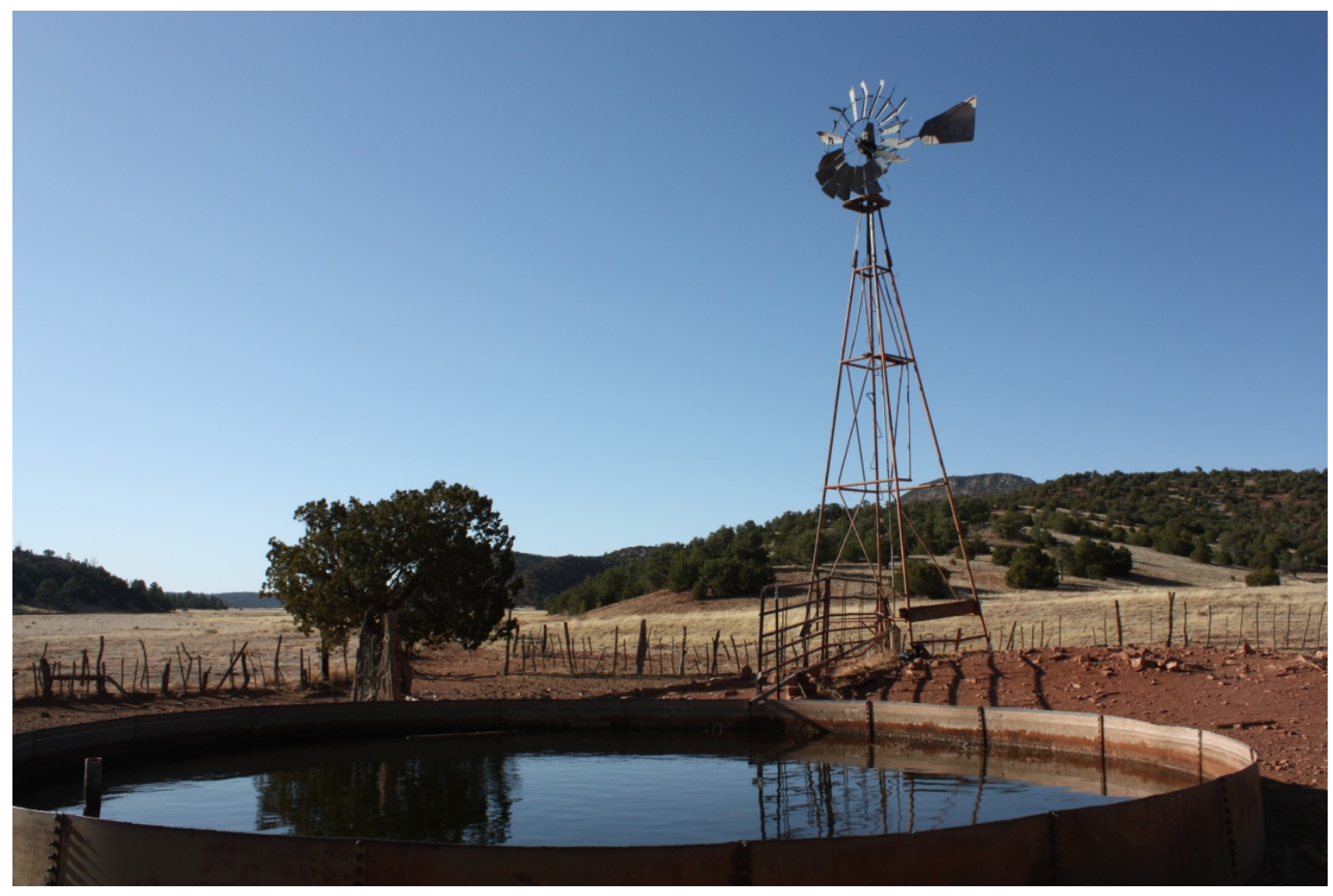

Bonita Canyon III (Lat 34 59' 28.5" N; Long: $107^{\circ}, 57^{\prime} 3.6$ ' W, elev. 7,152 ft (2,180 m); 2 netnights for 2011): This net site was located near the mouth of Bonita Canyon, in Cibola National Forest and was netted by Valdez and others (2002). Unlike the netting efforts by Valdez and others (2002), there was no overflow from the metal tank during the 2011 netting efforts. Also, there were no noticeable patches of grasses or forbs directly around the tanks, and surrounding grasses away from the tank were dead. Stands of piñon-juniper and ponderosa pine on either side of Bonita Canyon remain unchanged. On May 4, 2011, 4 (male) E. fuscus, 18 (16 male, 2 female) L. noctivagans, and 24 (23 male, 1 female) $M$. ciliolabrum were netted. These captures were the only individuals netted across four dates and at three locations between March 29 and May 18, 2011. Warm temperatures and a lull in wind gusts allowed for captures during May 4, 2011. Net success did not resume until June 6, 2011 at Cerro Hueco 2. 


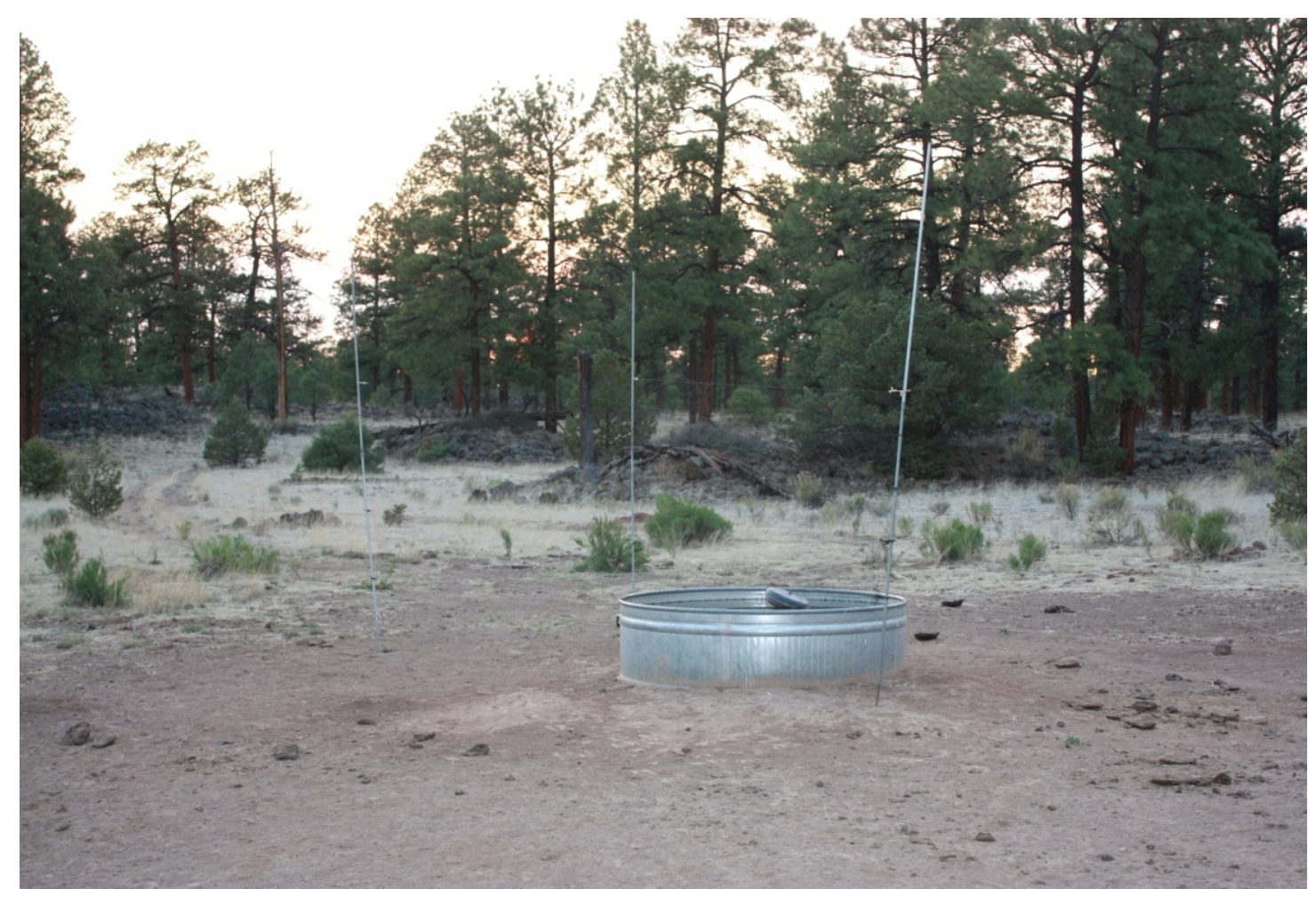

Braided Cave Tank (Lat 34 54' 19.9" N, Long 108 06' 58.4" W; 7,490 ft (2,283 m); 4 net-nights): This site is located on BLM land and near the park boundary, approximately $0.3 \mathrm{mi}(0.5 \mathrm{~km})$ north of the Braided Cave trailhead on ELMA. Surrounding habitat was mostly ponderosa pine with scattered piñon pine, shrubs, and grasses. This site was netted on June 9 and 30, 2011, with a total of 18 bats captured. On June 9, captures included 5 (male) M. evotis, whereas on June 30, captures included 1 (male) C. townsendii, 1 (male) M. ciliolabrum, 10 (male) M. evotis, and 1 (pregnant female) $M$. thysanodes. 


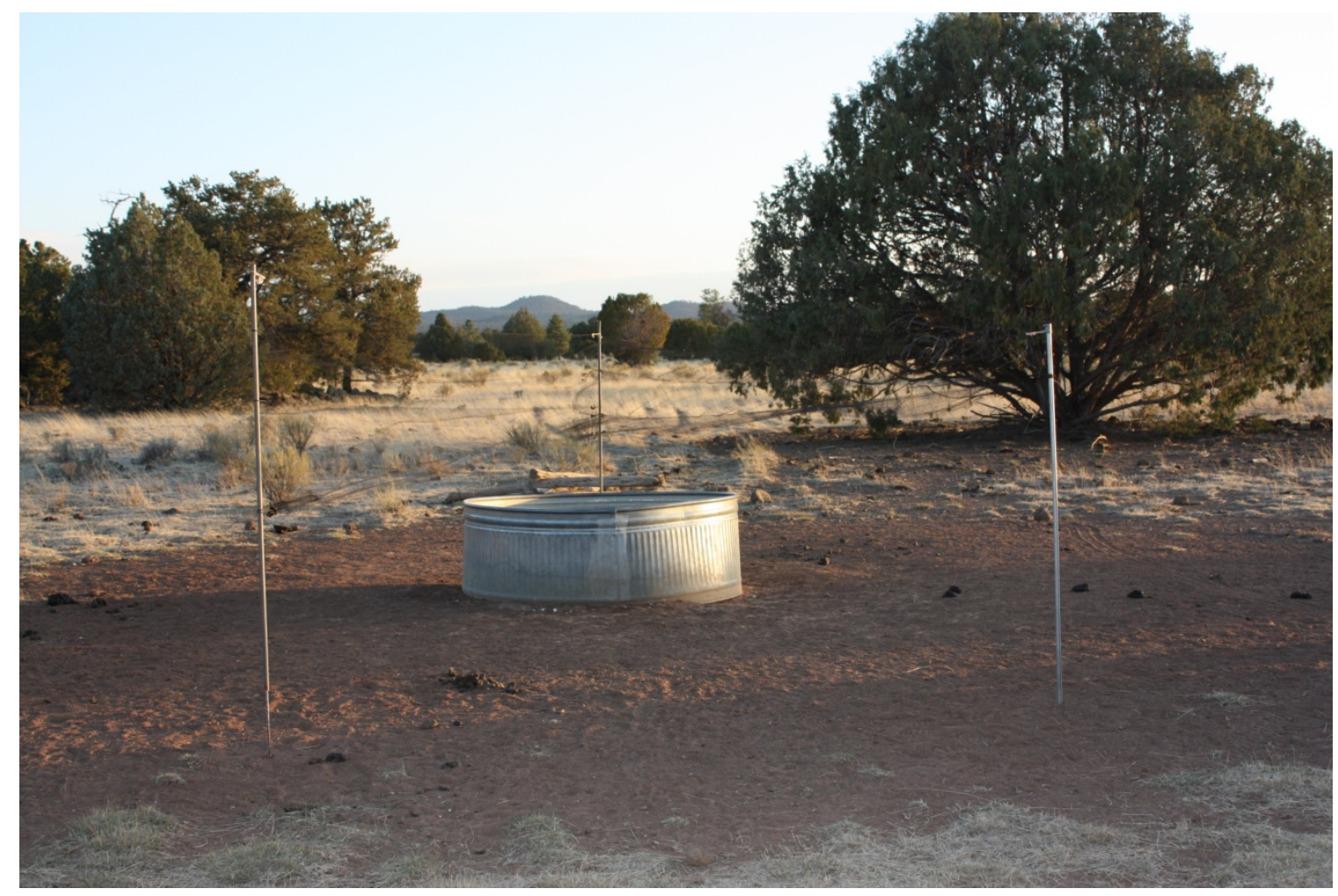

Cerro Americano (Lat $34^{\circ} 54^{\prime} 47.5^{\prime \prime}$ N, Long $108^{\circ} 10^{\prime} 32.4^{\prime \prime}$ W; elev. 7,612 ft (2,320 m); 4 netnights): This net site is located on BLM land, south of the extinct volcanic cone Cerro Americano and was a site that had been netted by Valdez and others (2002). A metal stock tank approximately $8 \mathrm{ft}(2.4$ $\mathrm{m}$ ) in diameter was the main source of water and was surrounded by piñon-juniper woodland habitat with scattered shrubs and mixed grasses. This site was netted on March 29 and May 5, 2011, but no bats were captured on either night. Wind and temperature were likely contributing factors to the lack of captures. 


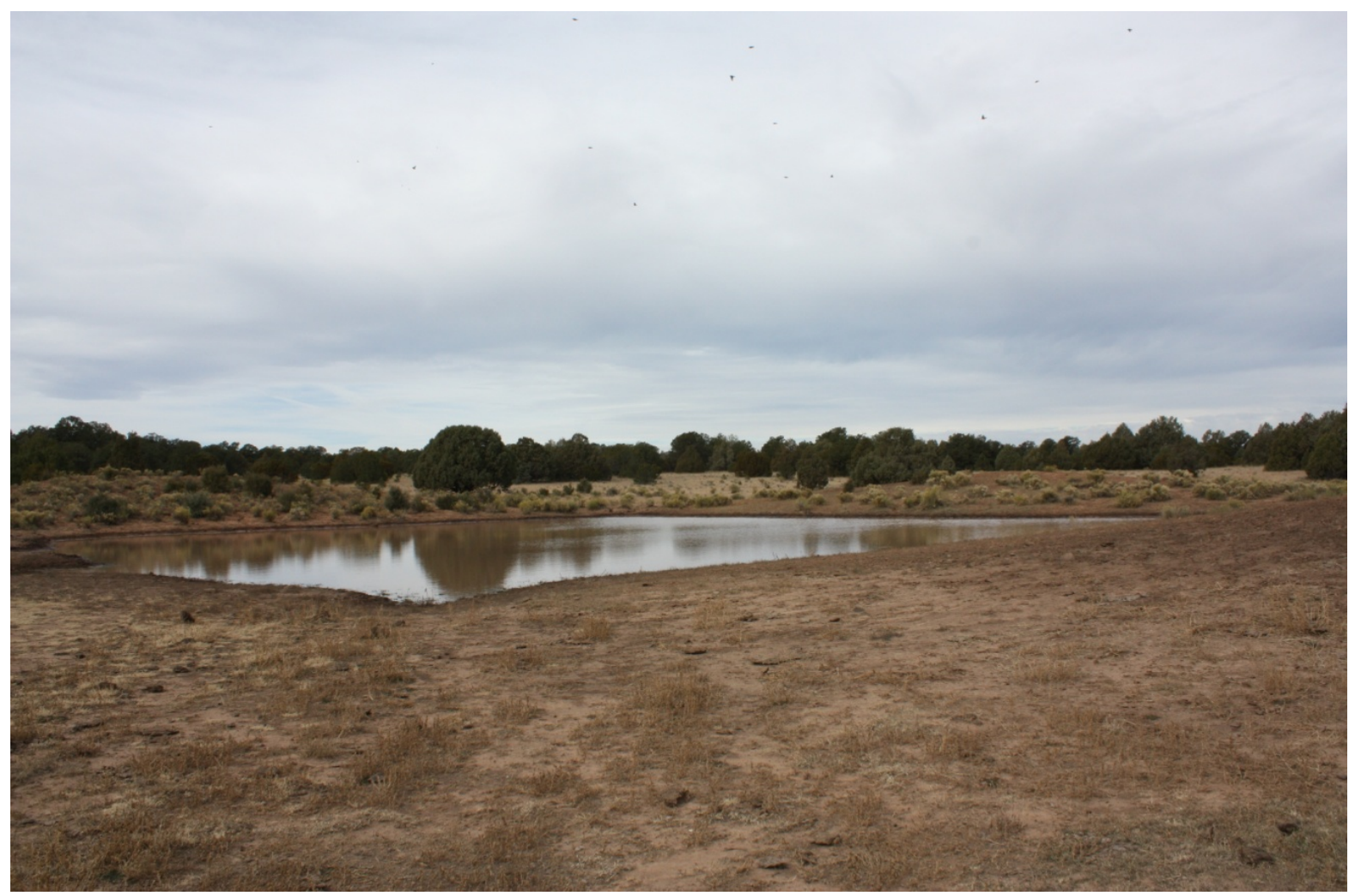

Cerrito Comadre I (Lat $34^{\circ} 57^{\prime} 11.2^{\prime \prime} \mathrm{N}$, Long $108^{\circ} 10^{\prime} 02.7^{\prime \prime} \mathrm{W}$; elev. 7,634 ft (2,327 m); 7 netnights): This net site is located on BLM land, west of the extinct volcanic cone Cerrito Comadre and was a site that had been netted by Valdez and others (2002). The earthen pond, where nets were placed, was about $80 \mathrm{ft}(24 \mathrm{~m})$ long and $40 \mathrm{ft}(12 \mathrm{~m})$ wide at the time of netting, but it had increased in size after the onset of monsoon rains, when the above photo was taken. Surrounding vegetation consisted primarily of piñon-juniper woodland with scattered shrubs and grasses. This site was netted on June 7 and August 3, 2011, with a total of 47 bats captured. On June 7, 5 (4 male, 1 female) E. fuscus, 4 (3 male, 1 female) L. noctivagans, 17 (male) M. ciliolabrum, 19 (male) M. evotis, and 2 (male) M. volans were netted, whereas no bats were captured on August 3. The lack of captures on August 3 was likely attributable to wind gusts and other available water sources from monsoon rains. 


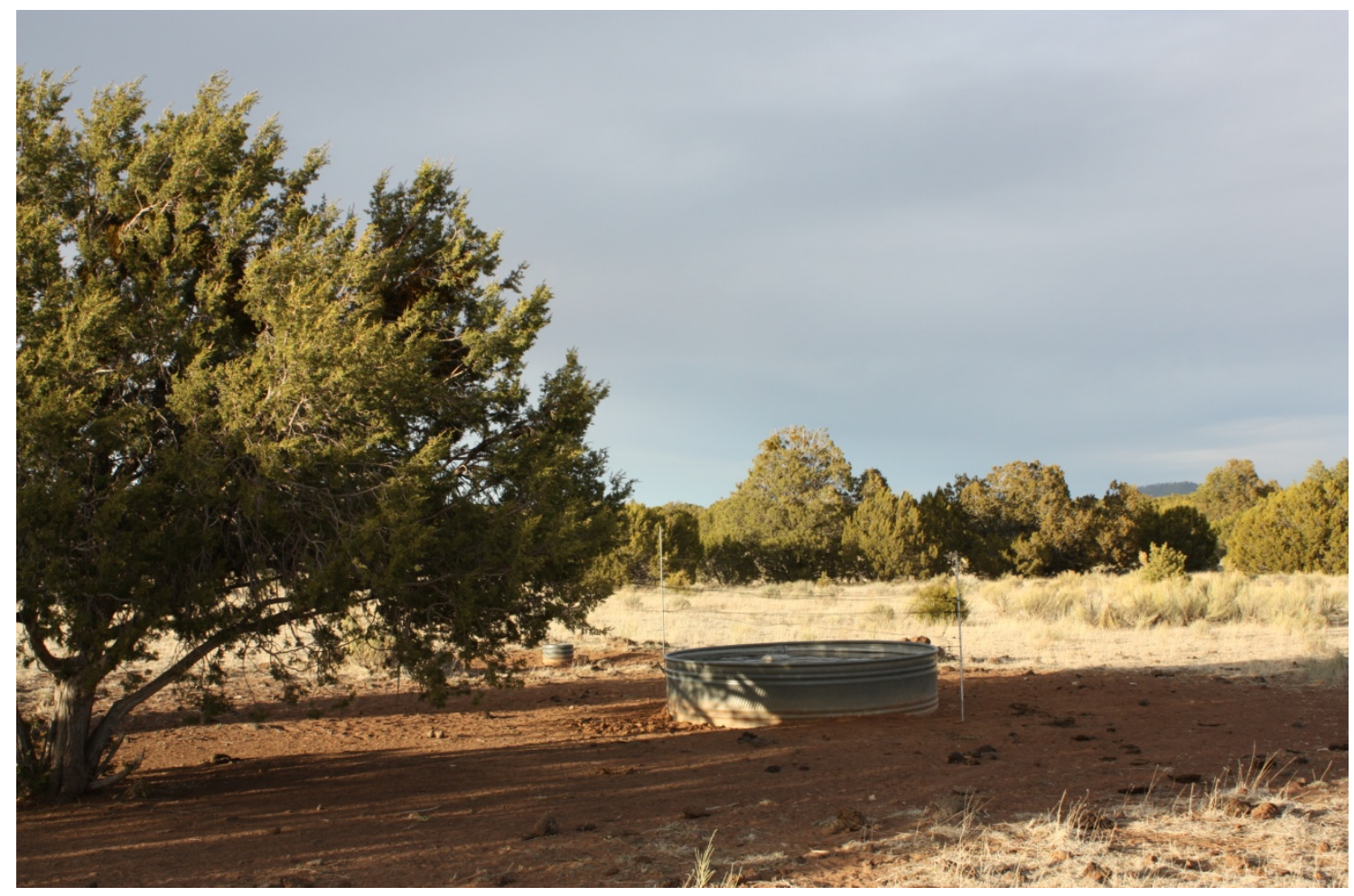

Cerrito Comadre II (Lat 34 ${ }^{\circ}$ 57' 21.3" N, Long $108^{\circ} 11^{\prime} 22.7^{\prime \prime}$ W; elev. 7,628 ft (2,322 m); 2 netnights). This net site was located on BLM land approximately $1.7 \mathrm{mi}(2.8 \mathrm{~km})$ west of the extinct volcanic cone Cerrito Comadre and $1.3 \mathrm{mi}(2.1 \mathrm{~km})$ west of net site Cerrito Comadre I. A metal stock tank approximately $8 \mathrm{ft}(2.4 \mathrm{~m})$ in diameter was the main source of water and was surrounded by piñonjuniper woodland habitat with scattered shrubs and mixed grasses. This site was netted only on May 17, 2011, with no bats captured. Wind and a full moon were likely the contributing factors for the lack of captures. 


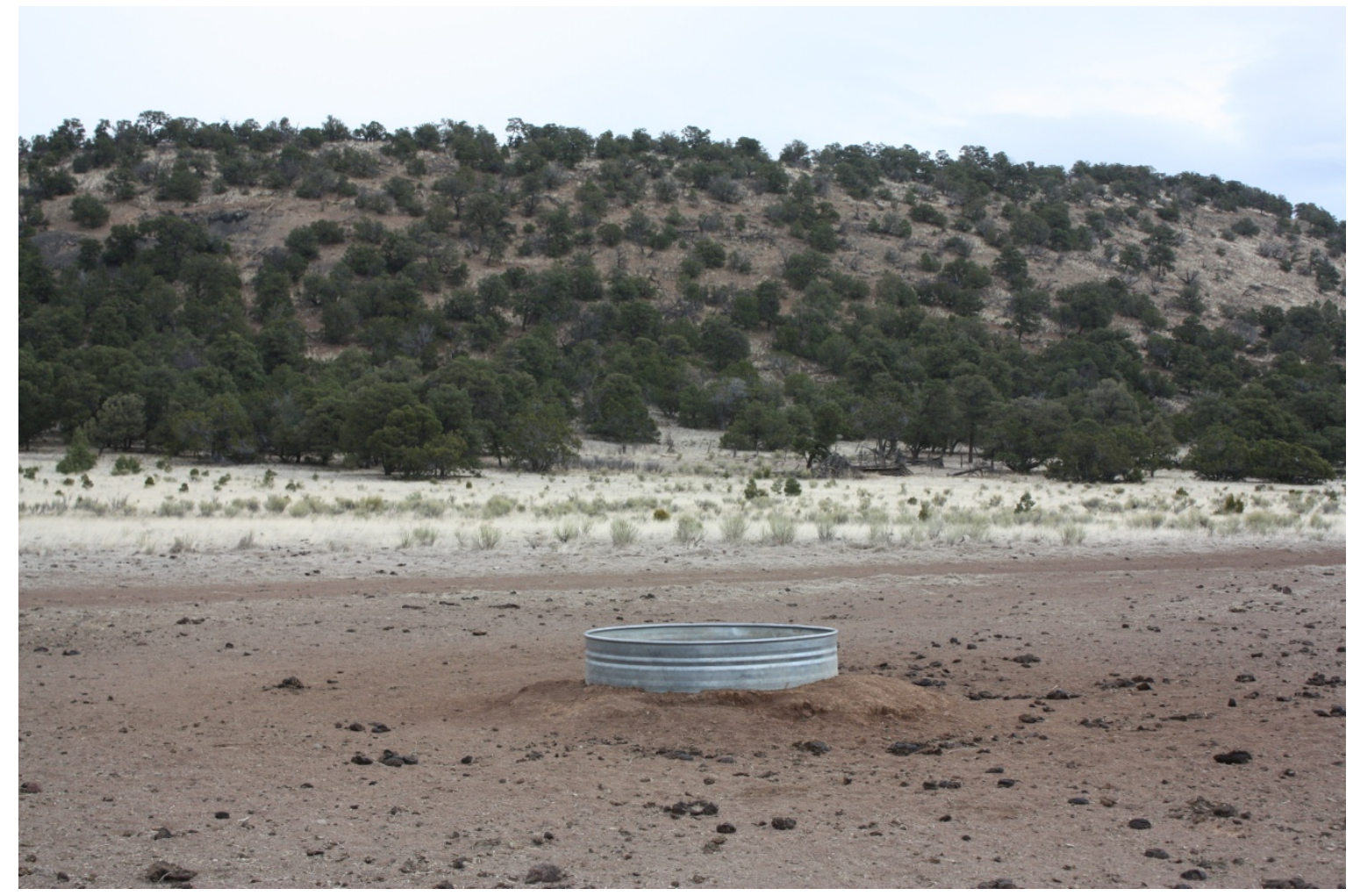

Cerro Hueco I (Lat $34^{\circ}$ 52.548' N, Long $108^{\circ}$ 09.953' W; elev. 7,654 ft (2,333 m); 1 net-night): This net site is located on BLM land, southwest of the extinct volcanic cone Cerro Hueco and was a site that had been netted by Valdez and others (2002). A metal stock tank approximately $8 \mathrm{ft}(2.4 \mathrm{~m})$ in diameter was the main source of water and was located in an open area with scattered shrubs and grasses, as well as neighboring piñon-juniper woodland. This site was netted only on May 18, 2011, with no bats captured. Wind, cold temperatures, and snow were the likely contributing factors for lack of captures. 


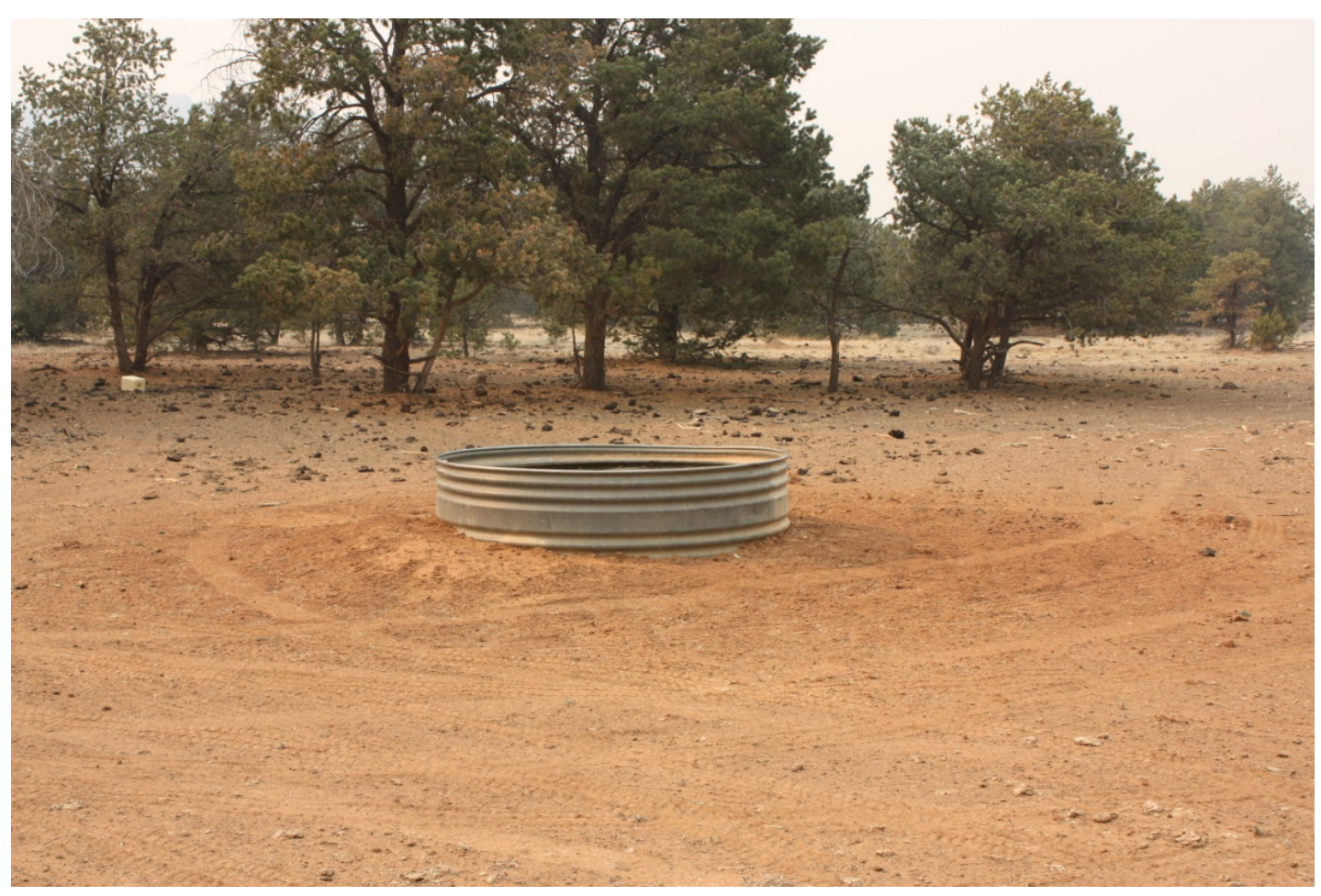

Cerro Hueco II (Lat 34 ${ }^{\circ}$ 52' 32.5" N, Long 108 09' 57.2" W; elev. 7,566 ft (2,306 m); 4 net-nights): This net site is located on BLM land, south of the extinct volcanic cone Cerro Hueco and had been netted multiple times by Valdez and others (2002). A metal stock tank approximately $8 \mathrm{ft}(2.4 \mathrm{~m})$ in diameter was the main source of water and was located in piñon-juniper woodland. On June 6,1 (female) M. ciliolabrum, 2 (male) M. evotis, and 2 (female) M. thysanodes were netted, whereas on June 29, 4 (male) M. evotis and 1 (male) M. thysanodes were netted. 


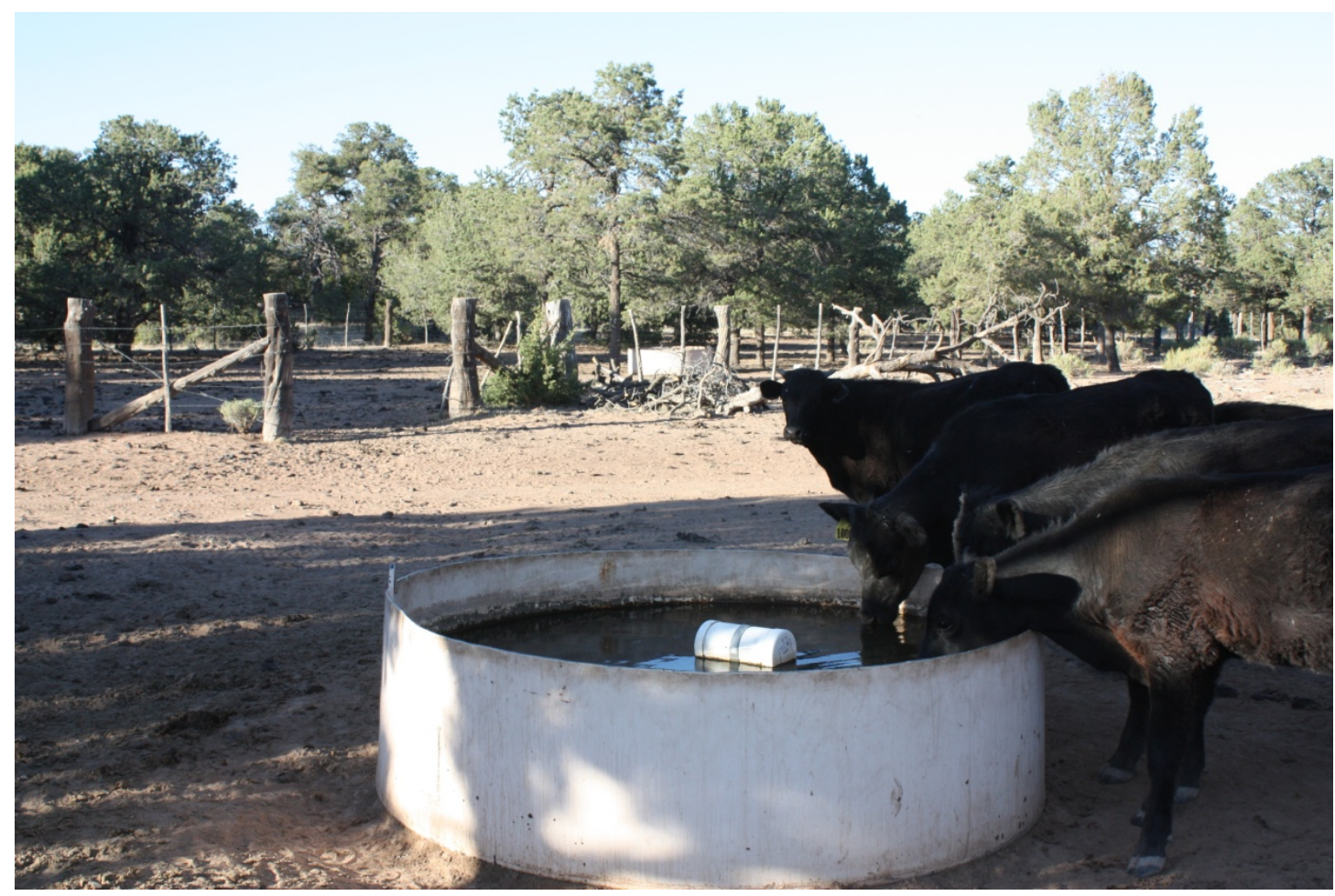

Cerro Lobo I (Lat 34 50' 37.9" N, Long 108 11' 42.1" W; elev. 7,493 ft (2,284 m); 3 net- nights): This net site is located on the edge of BLM property and near a private inholding, about $1.5 \mathrm{mi}(2.4 \mathrm{~km})$ east of the extinct volcanic cone Cerro Lobo. Two metal stock tanks approximately $6 \mathrm{ft}(1.8 \mathrm{~m}) \mathrm{in}$ diameter were the main sources of water and were located in piñon-juniper woodland habitat. One of the tanks was enclosed by a corral. On June 24, 3 (male) M. ciliolabrum, 11 (male) M. evotis, 4 (3 male, 1 female) M. thysanodes were captured. 


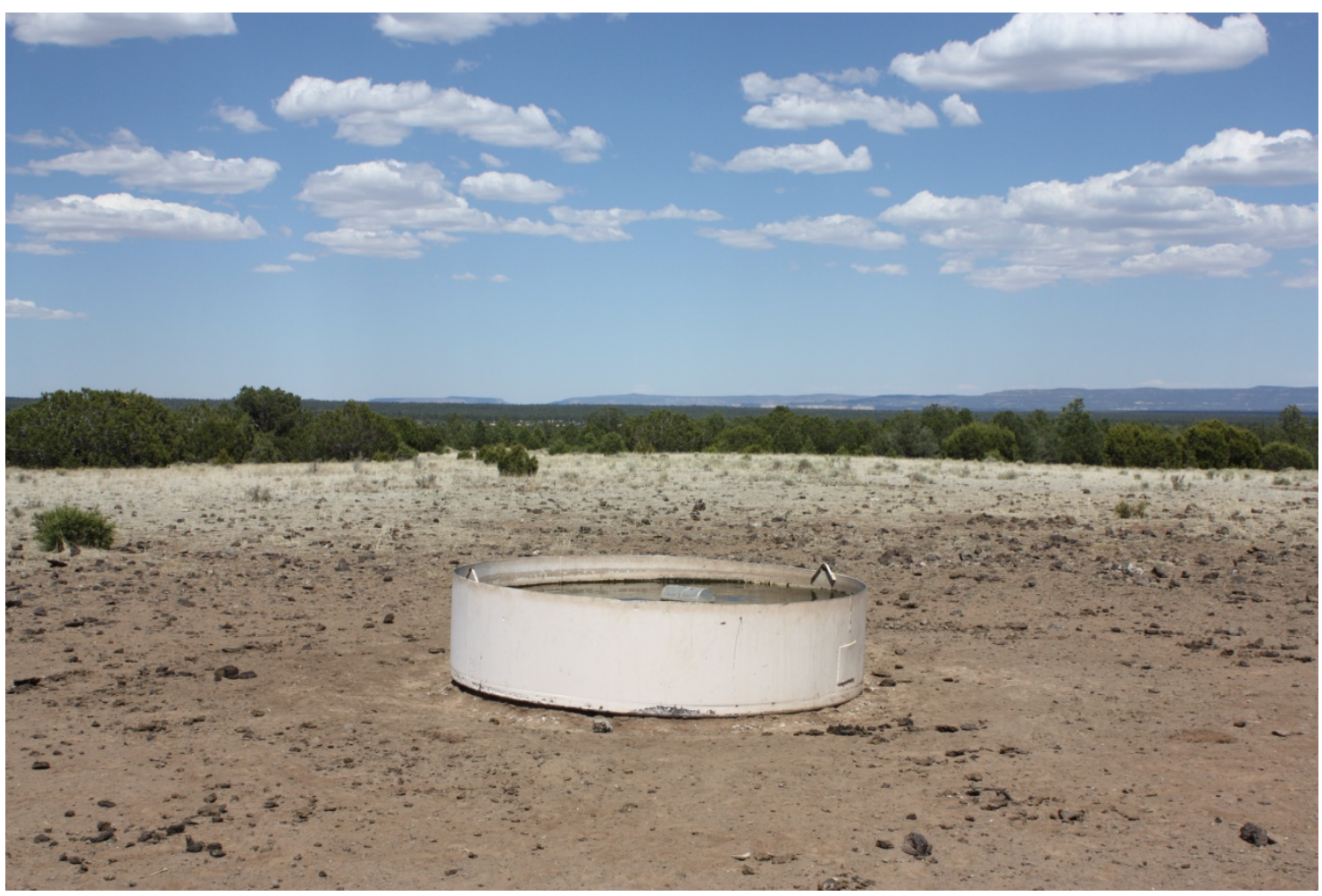

Cerro Lobo II (Lat 34 49' 51" N, 108 ${ }^{\circ}$ 10' 25.5" W; elev. 7,460 ft (2,274 m); 2 net-nights): This net site is located on BLM land, approximately $3.1 \mathrm{mi}(5 \mathrm{~km})$ southeast of the extinct volcanic cone Cerro Lobo. A metal stock tank approximately $6 \mathrm{ft}(1.8 \mathrm{~m})$ in diameter was the main source of water and was located in an open area with scattered shrubs and grasses, surrounded by piñon-juniper woodland. This site was netted only on July 1, 2011, with no bats captured, although 2 bats were observed flying nearby before wind gusts reached greater than $6.2 \mathrm{mph}(10 \mathrm{kmph})$. Wind and rain were the likely contributing factors for the lack of captures. 


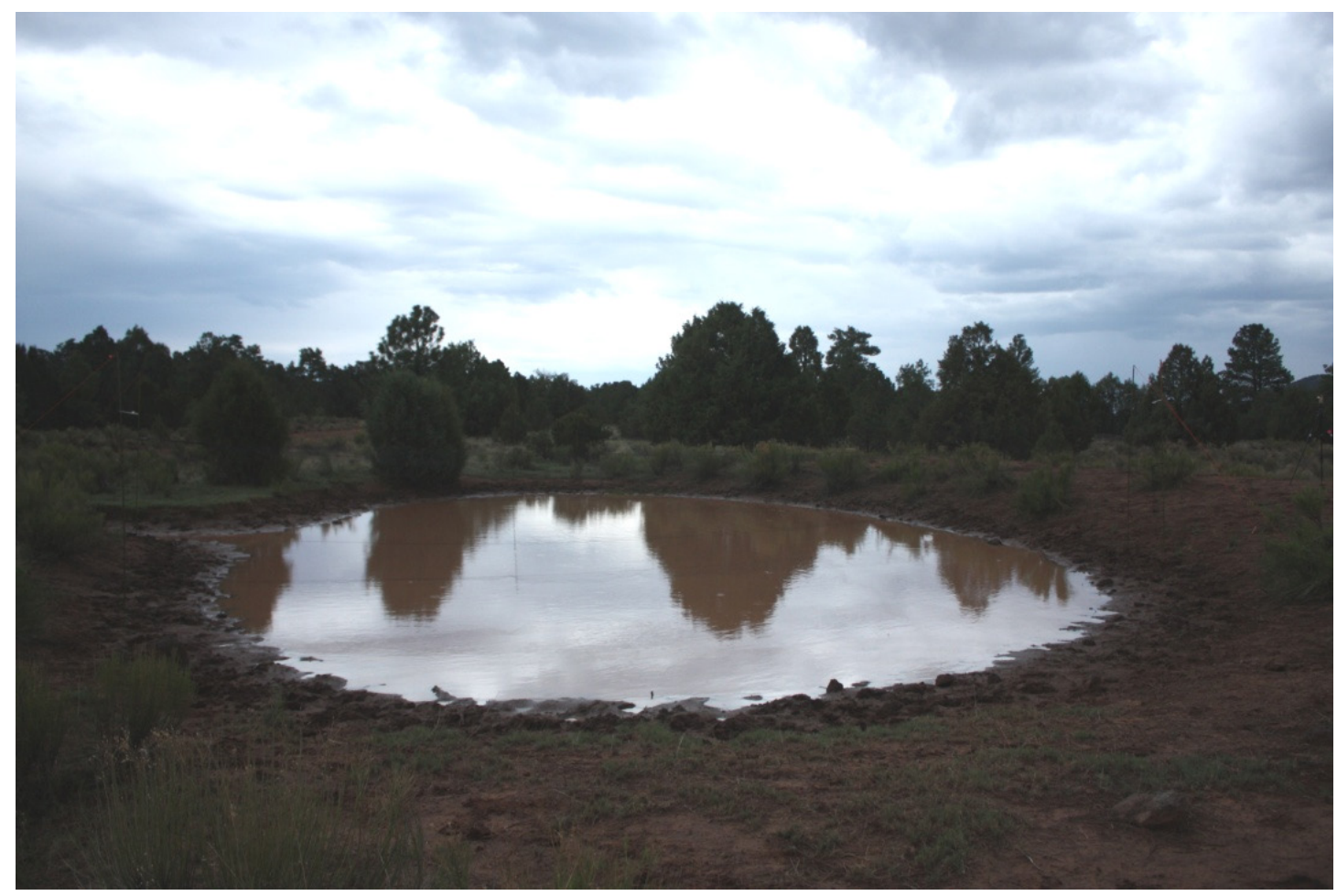

Cerro Rendija I (Lat $34^{\circ} 57^{\prime} 11.6^{\prime \prime}$ N, $108^{\circ} 8^{\prime} 43.6^{\prime \prime}$ W; elev. 7,644 ft (2,330 m); 6 net-nights): This net site is located on BLM land, west of the extinct volcanic cone Cerro Rendija, about $20 \mathrm{ft}(6 \mathrm{~m})$ west of County Road 42, and had been netted by Valdez and others (2002). This site was an earthen stock pond, intermittently filled by rains, and about $50 \mathrm{ft}(15.2 \mathrm{~m})$ long and $30 \mathrm{ft}(9.1 \mathrm{~m})$ wide, but did not have water until July, 2011. The surrounding vegetation consisted mostly of piñon-juniper with nearby ponderosa pines on the extinct volcanic cone Cerro Rendija. This locality was netted on July 29 and August 5 with only 5 bats captured on August 5 that included 1 (male) M. ciliolabrum, 3 (male) M. evotis, and 1 (male) M. thysanodes. These few captures, compared to those reported by Valdez and others (2002), likely is attributed to the late presence of water and availability of other water resources during this time. 


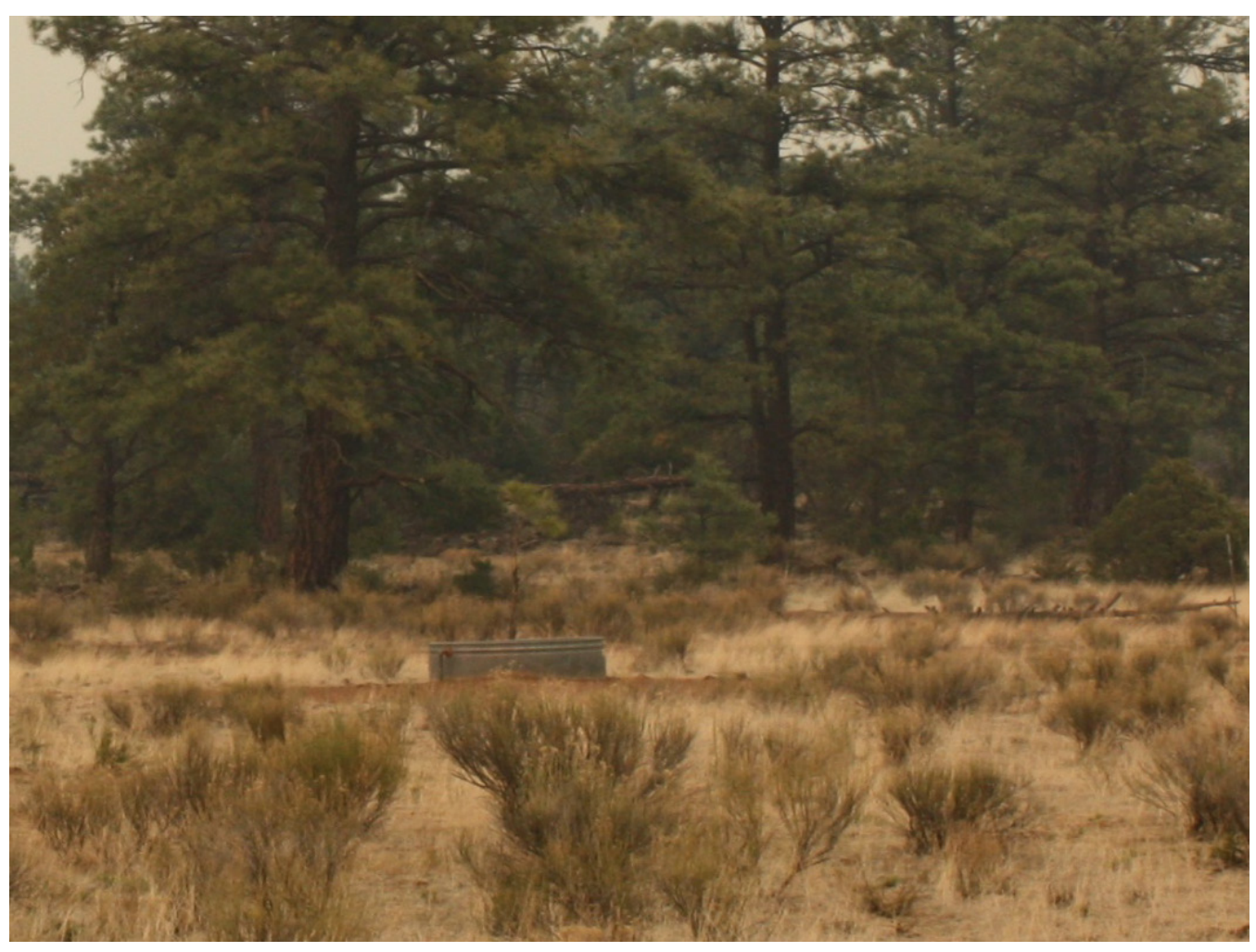

Cerro Rendija II (Lat $34^{\circ} 55^{\prime} 11.9^{\prime \prime}$ N, Long $108^{\circ}$ 06' 20.5" W; elev. 7,507 ft (2,288 m); 4 netnights): This net site is located on BLM land approximately $1.5 \mathrm{mi}(2.4 \mathrm{~km})$ southeast of the extinct volcanic cone Cerro Rendija and had been netted by Valdez and others (2002). A metal stock tank approximately $8 \mathrm{ft}(2.4 \mathrm{~m})$ in diameter was the main source of water. This stock tank was surrounded by mostly ponderosa pine as well as scattered shrubs and grasses. Nearby was a large earthen basin that likely served as an overflow reservoir for the stock tank. This earthen basin was dry during netting efforts of 2011. The main water source at Cerro Rendija was netted on June 8 and 28, 2011, with a total of 8 bats netted. On June 8, 1 (female) C. townsendii, 5 (male) M. evotis, 2 (male) M. thysanodes were netted at the metal stock tank. Because of rain and wind gusts, no bats were captured on June 28. 


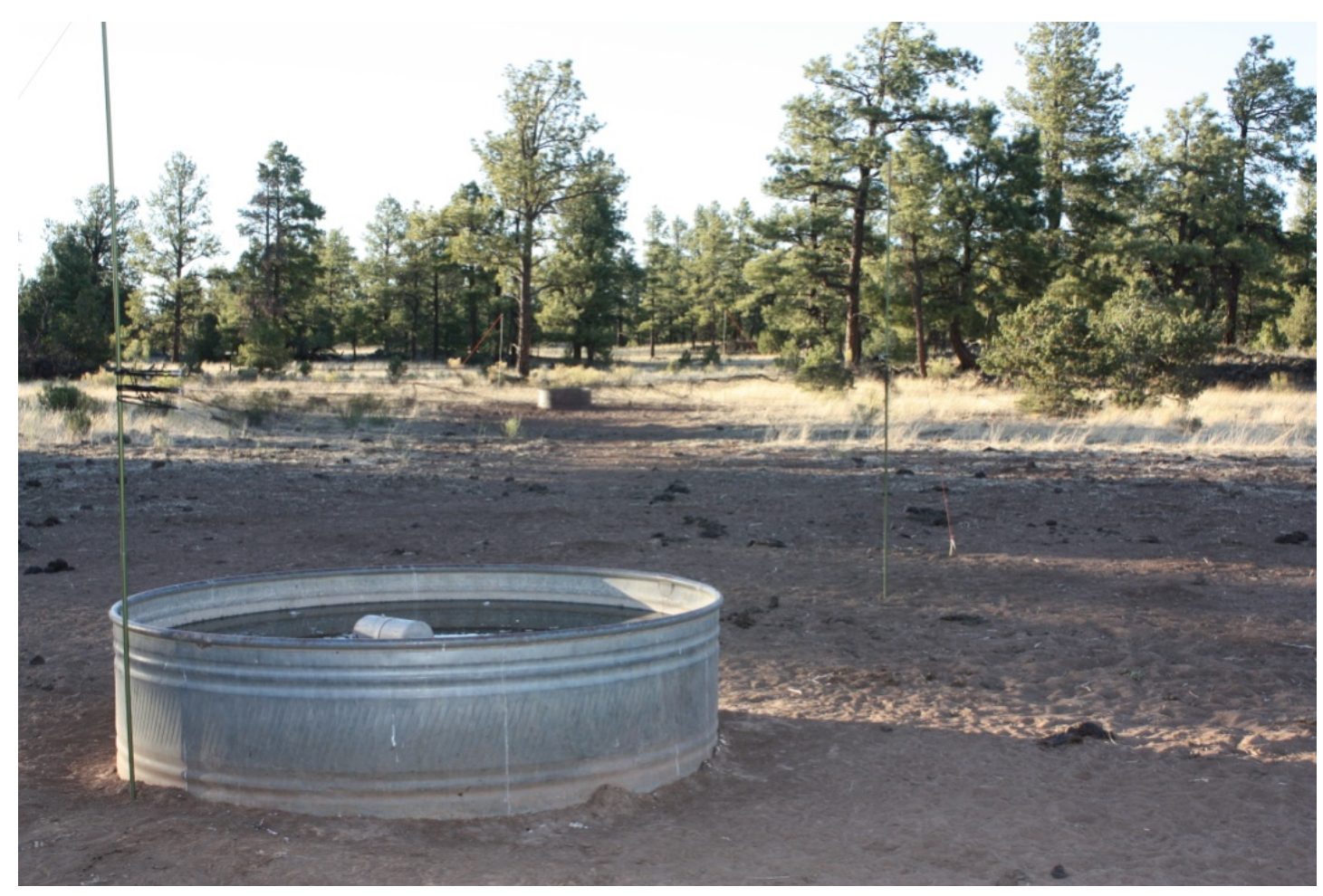

Cerro Rendija III (Lat 34 54' 52" N, Long $108^{\circ} 066^{\prime} 6.8^{\prime \prime}$ W; elev. 7,484 ft (2,281 m); 6 net-nights): This net site is located on BLM land approximately $1.8 \mathrm{mi}(2.9 \mathrm{~km})$ southeast of the extinct volcanic cone Cerro Rendija. There were two metal stock tanks that were netted at this site; the larger of the two was approximately $8 \mathrm{ft}(2.4 \mathrm{~m})$ in diameter, whereas the smaller was about $6 \mathrm{ft}(1.8 \mathrm{~m})$ in diameter. Like many net sites near the extinct volcanic cone Cerro Rendija, these stock tanks were surrounded mostly by ponderosa pine forest, with scattered piñon pine, shrubs, and grasses. This site was netted on June 22 and July 26, 2011, with a total of 39 bats netted. On June 22, 1 (male) M. ciliolabrum, 28 (26 male, 2 female) M. evotis, and 4 (male) M. thysanodes were netted, whereas on July 26, 3 (2 male, 1 lactating female) $M$. evotis, and 3 (male) $M$. thysanodes were captured. The greater number of captures on June 22 and fewer captures on July 26 coincides with abundance of water sources (See fig. 3). 


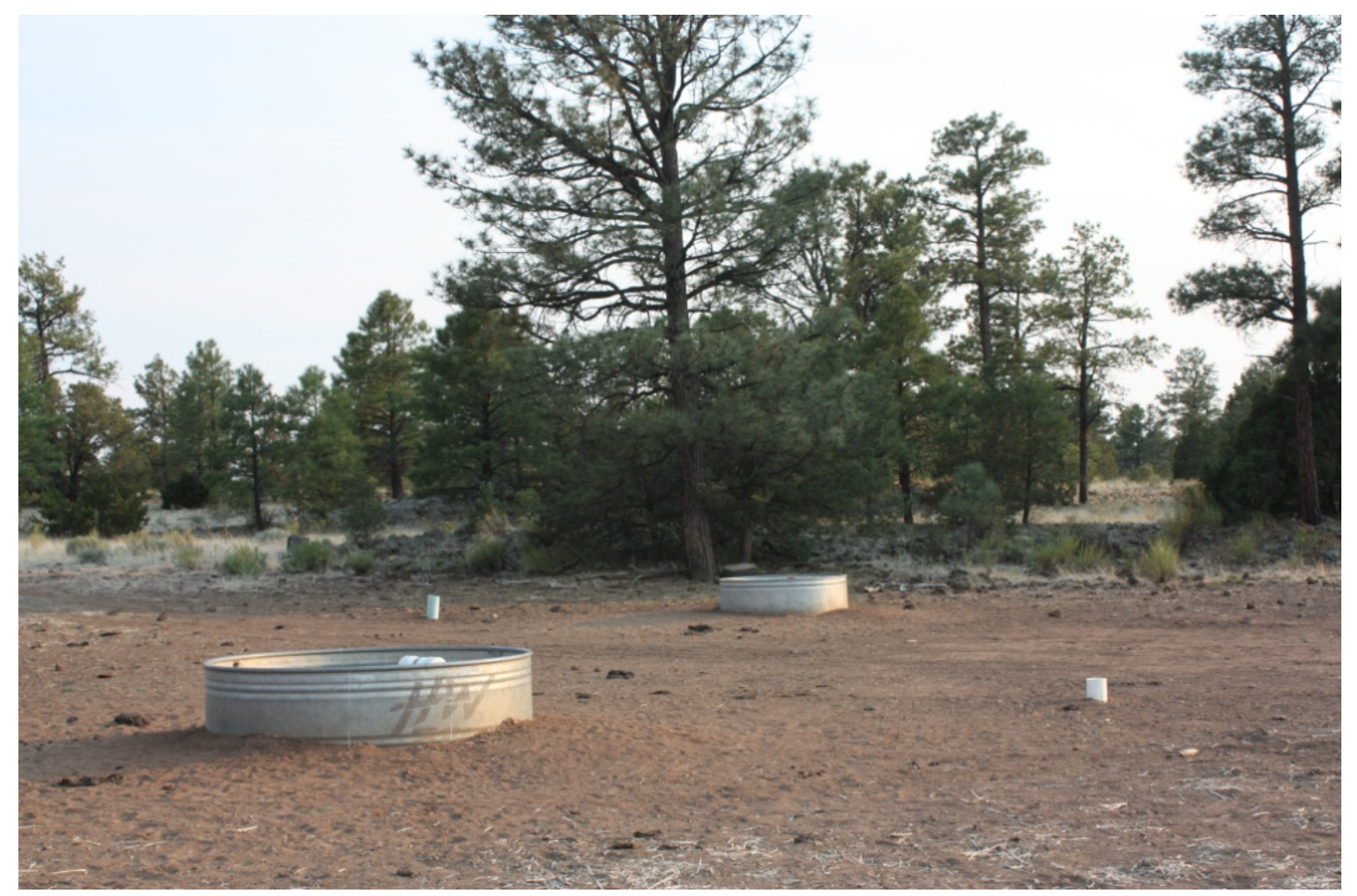

Cerro Rendija IV (Lat $34^{\circ}$ 55' 10.5" N, Long $108^{\circ} 07^{\prime} 27.3 "$ W; elev. 7,549 ft (2,301 m); 8 netnights): This net site is located on BLM land approximately $1.3 \mathrm{mi}(2.1 \mathrm{~km})$ south-southwest of the extinct volcanic cone Cerro Rendija. Like Cerro Rendija III, there were two metal stock tanks that were netted at this site. However, both were equal in size, approximately $8 \mathrm{ft}(2.4 \mathrm{~m})$ in diameter. These water sources were surrounded by ponderosa pine forest, as well as scattered piñon pine, shrubs, and grasses. These water sources were netted on June 10 and August 1 with a total of 14 bats captured. Of these, 12 (male) M. evotis and 1 (male) M. thysanodes were captured on June 10, whereas a single M. evotis (male) was netted on August 1. Difference in capture success is likely related to the amount of water available. 


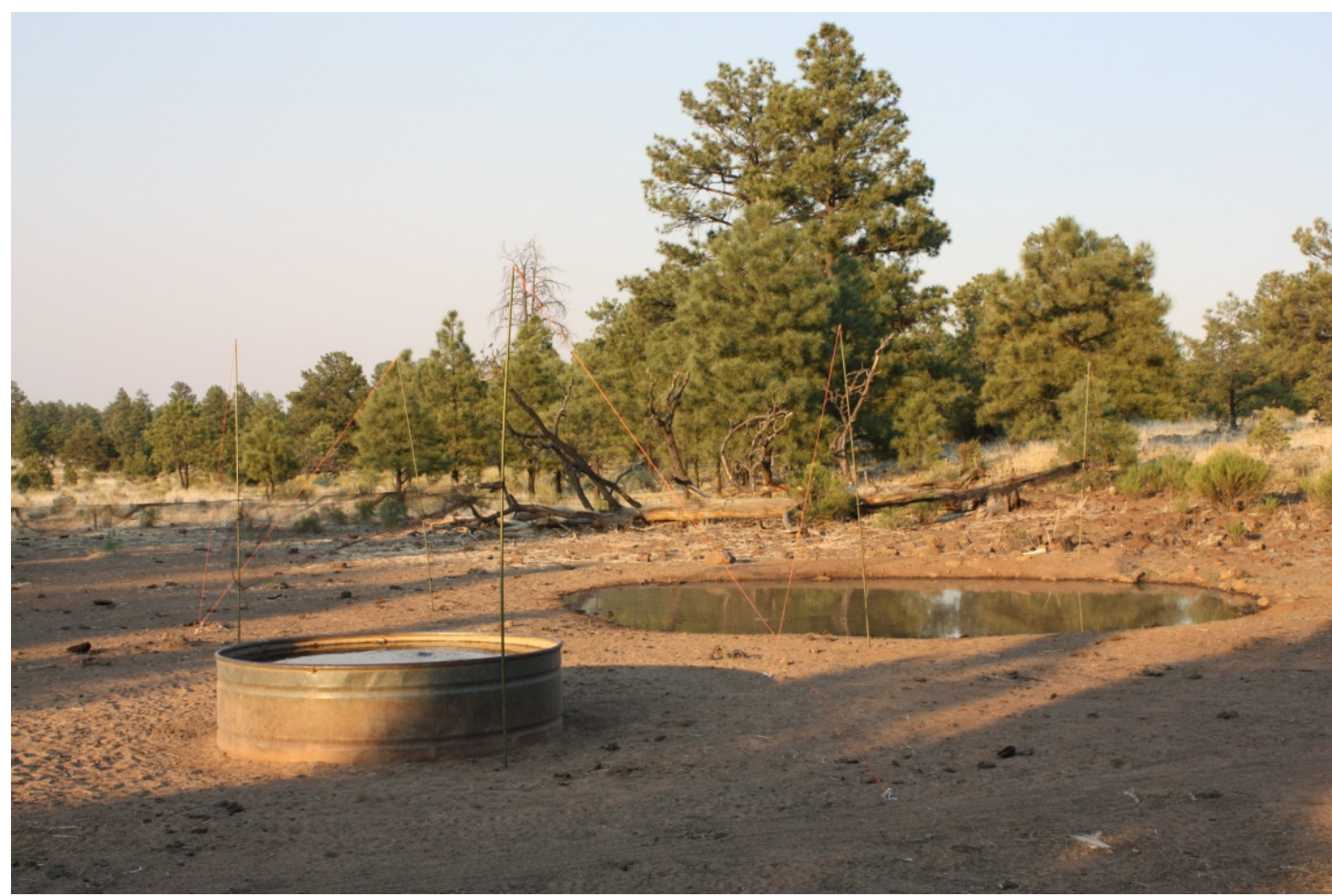

Cerro Rendija V (Lat $34^{\circ} 55^{\prime} 35.1^{\prime \prime}$ N, Long $108^{\circ} 07^{\prime} 46.2^{\prime \prime}$ W; elev. 7,592 ft (2,314 m); 8 netnights): This net site is located on BLM land approximately $0.6 \mathrm{mi}(1 \mathrm{~km})$ south of the extinct volcanic cone Cerro Rendija. The main source of water was a metal stock tank, approximately $8 \mathrm{ft}(2.4 \mathrm{~m})$ in diameter. However, nearby was an overflow pond from the stock tank at about $33 \mathrm{ft}(10 \mathrm{~m})$ wide by 30 $\mathrm{ft}(9 \mathrm{~m})$ long. The surrounding habitat was composed of mixed ponderosa and piñon pines, with scattered shrubs and grasses, and appeared to be transitional habitat between Cerro Rendija I and Cerro Rendija II-IV net sites. This net site was netted on June 23 and August 4, with a total of 35 bats captured. On June 23, 1 (male) C. townsendii, 2 (male) L. noctivagans, 2 (male) M. ciliolabrum, 20 (male) M. evotis, 5 (male) M. thysanodes, 1 (male) M. volans were captured, whereas on August 4, 1 (male) E. fuscus, 2 (male) M. evotis, and 1 (male) M. thysanodes were netted. Difference in capture success is likely related to the amount of water available. 


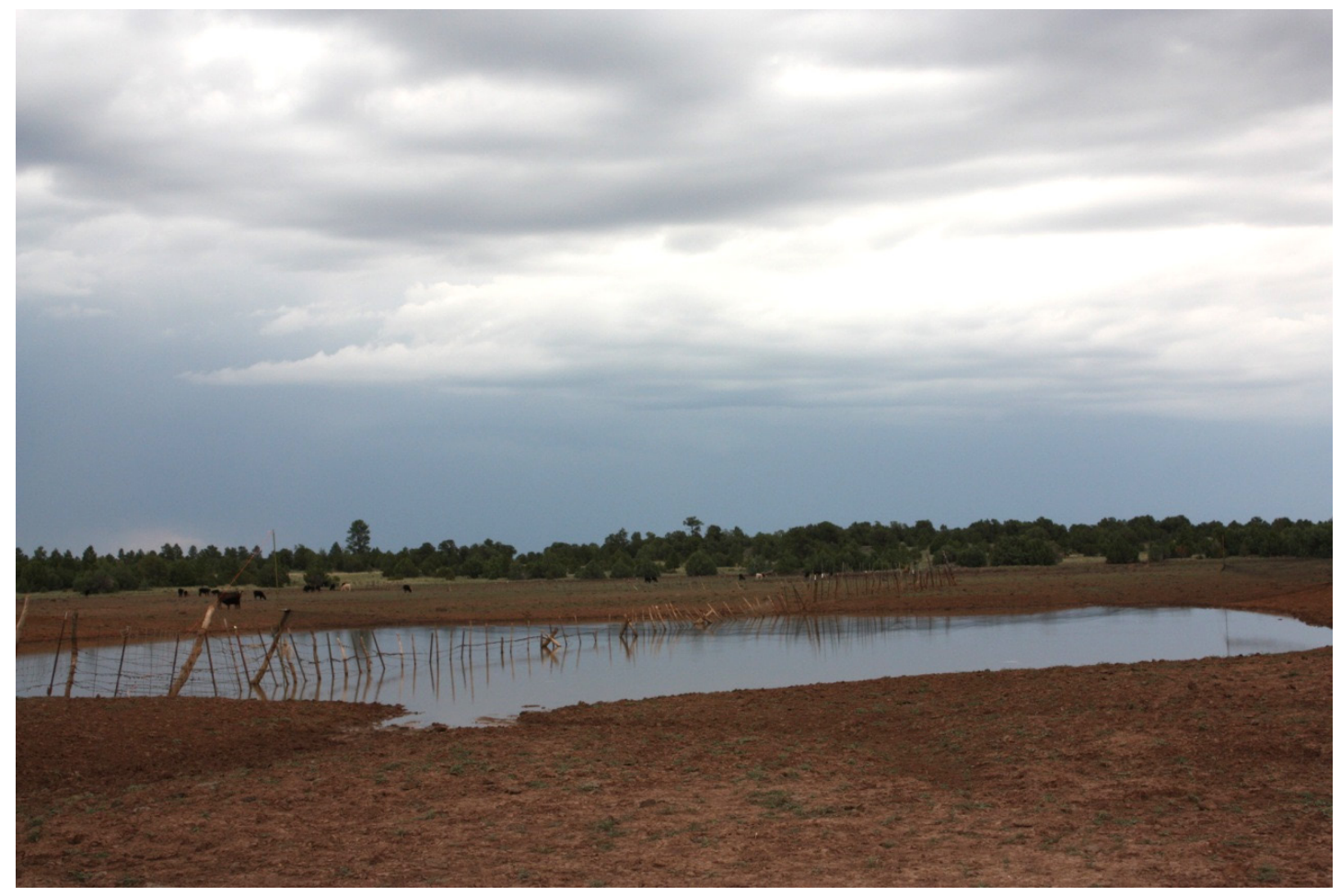

Laguna Americana (Lat 34 ${ }^{\circ}$ 55' 55.3" N, 108 9' 40.1" W; elev. 7,572 ft (2,308 m); 4 net-nights): This net site was one of the largest water sources netted during the summer of 2011. It is located on BLM land east of the extinct volcanic cone Cerro Americano and is filled by seasonal snow and rain. This water source was located in an open area/basin that contained mostly grasses and scattered shrubs; however, piñon-juniper woodland and ponderosa pine forest were nearby. On March 29, Laguna American was filled to its maximum limits at approximately $1,700 \mathrm{ft}(518 \mathrm{~m})$ long and $1,371 \mathrm{ft}(418 \mathrm{~m})$ at its widest. Because this water source was too large to net in the spring, it was not netted until July 27 , 2011, when water levels had gone down to approximately $118 \mathrm{ft}(36 \mathrm{~m})$ long by $89 \mathrm{ft}(27 \mathrm{~m})$ wide. This smaller pool was split in half by a barbed-wire boundary fence; therefore, only half was accessible to net. One bat was observed flying in the area; however, because of wind gusts and rain, the netting effort had to be abandoned. No bats were captured. 


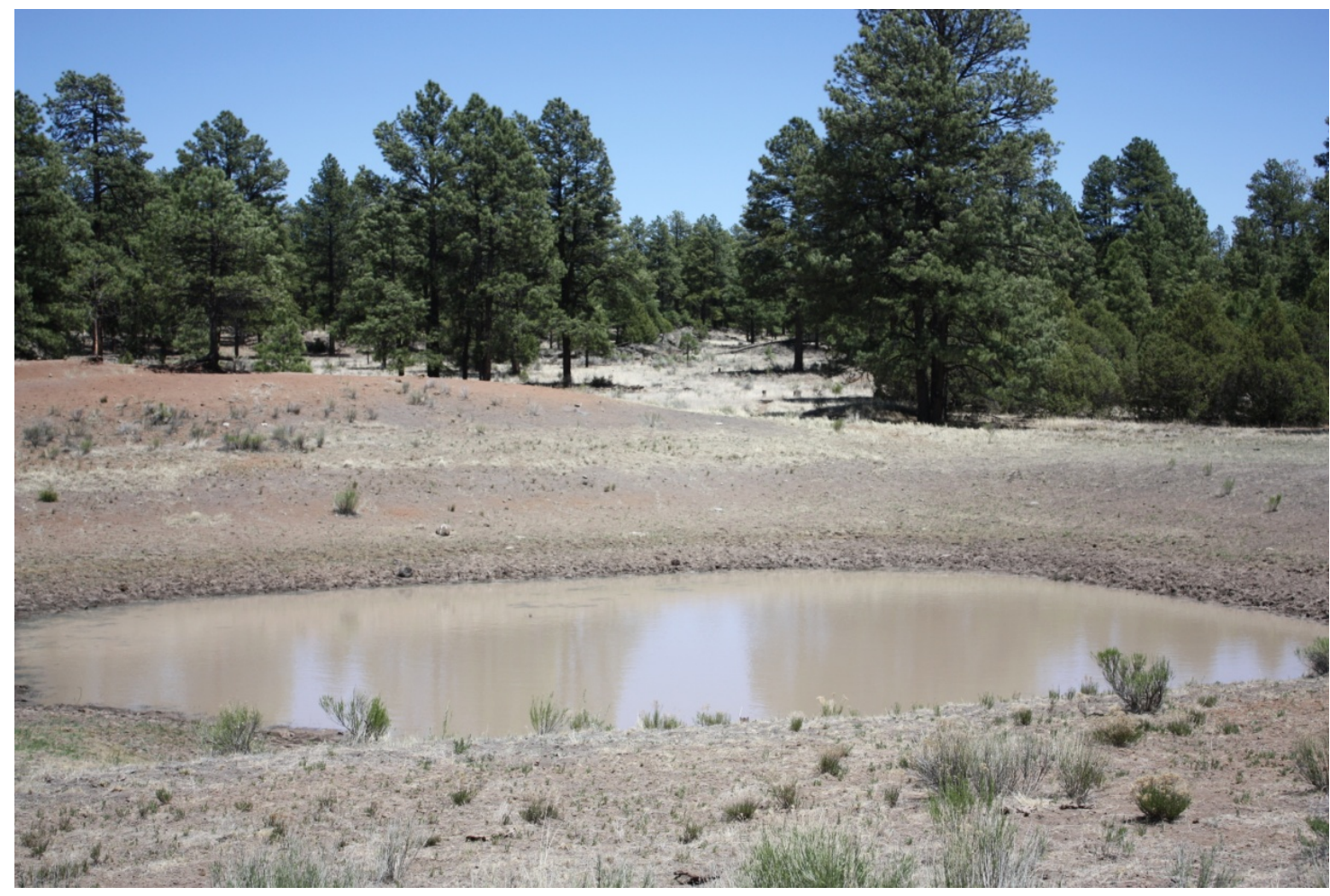

Laguna de Juan Garcia ( $34^{\circ} 59^{\prime} 16.0^{\prime \prime} \mathrm{N}, 1^{\circ} \mathbf{1 0 7}^{\circ}$ 07 30.4" W; 7,726 ft (2,355 m); 16 net-nights):

Laguna de Juan Garcia is the only known water source and net site on the park. This earthen pond is 92 $\mathrm{ft}(28 \mathrm{~m})$ long and $82 \mathrm{ft}(25 \mathrm{~m})$ wide, located within the northwestern edge of ELMA, and is surrounded by ponderosa forest and near transitional habitat of piñon-juniper woodland. Laguna de Juan Garcia is filled with seasonal precipitation but was observed during 2011 to have water during drought-like conditions of the early spring when other water resources were dry. The location of Laguna de Juan Garcia and its proximity to known and unknown hibernacula sites provides an opportunity for greater detection of WNS through mist-netting efforts. This net site was visited on June 20 and 27, July 25, and August 2 for a total of 155 bats captured, belonging to eight species including: C. townsendii, E. fuscus, L. noctivagans, M. ciliolabrum, M. evotis, M. thysanodes, M. volans, and T. brasiliensis. See table 4 for exact counts and sexes of bats netted on each date. 


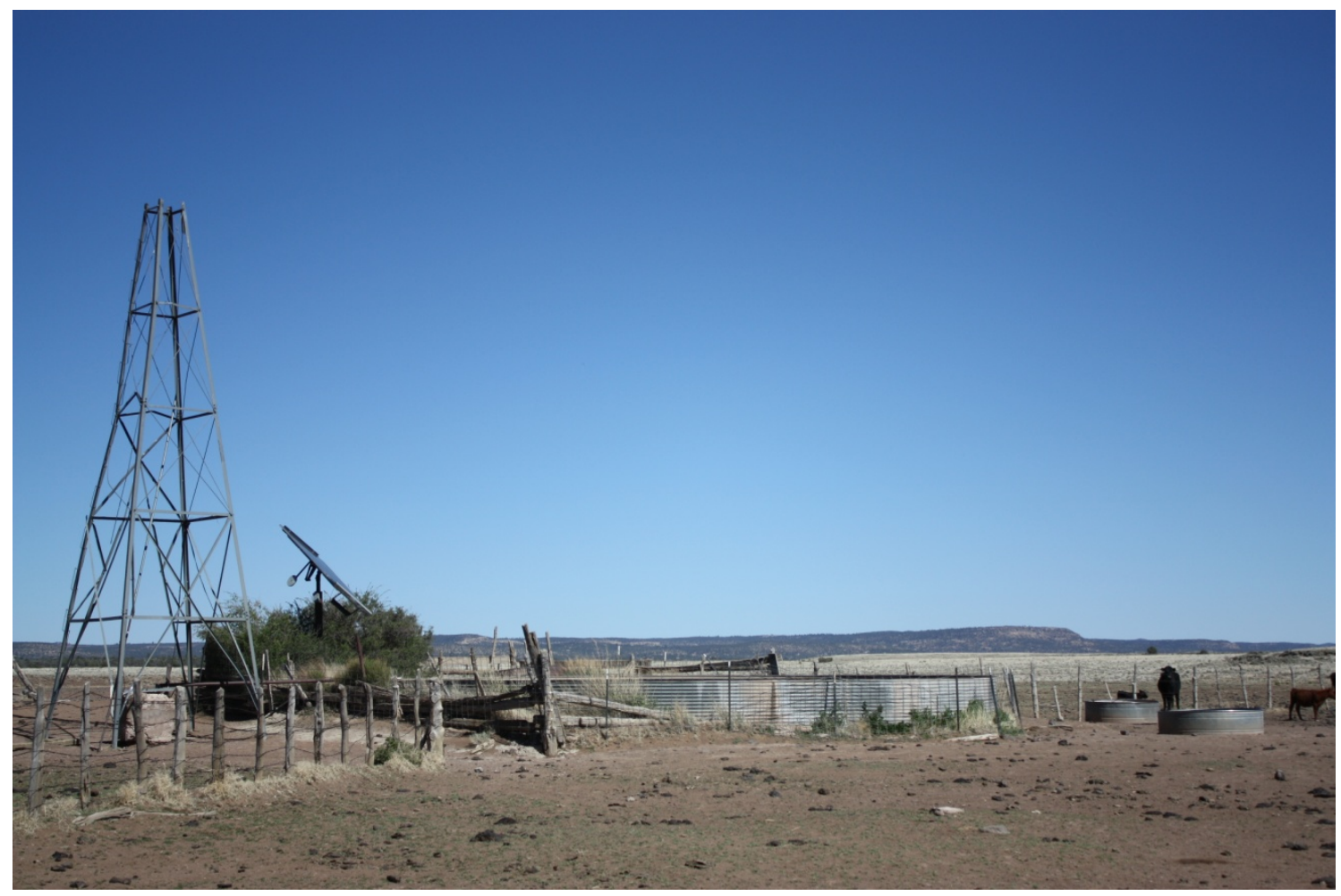

Windmill south of Prairie Dog Well I (Lat 34 44' 49.1" N, Long $108^{\circ} 2^{\prime} 51.4^{\prime \prime}$ W; elev. 7,103 ft $(2,165 \mathrm{~m}) ; 3$ net-nights): This net site is located on BLM land, approximately $4.5 \mathrm{mi}(7.2 \mathrm{~km})$ south and $4 \mathrm{mi}(6.4 \mathrm{~km})$ east of Prairie Dog Well, and appears to be on a historic homestead. This site was netted multiple times by Valdez and others (2002). The main water source is a large metal tank approximately $33 \mathrm{ft}(10 \mathrm{~m})$ in diameter that was once filled by a windmill that has now been converted to be powered by a solar panel. Two smaller tanks about $8 \mathrm{ft}(2.4 \mathrm{~m})$ in diameter are located nearby, but only one had water that could be netted. On June 21, a total of 26 bats were netted including 10 (male) E. fuscus, 4 (male) L. noctivagans, 10 (male) M. ciliolabrum, 1 (male) M. thysanodes, and 1 (male) $T$. brasiliensis. No A. pallidus were captured, as reported by Valdez and others (2002) during their efforts in 1999 and 2000. 


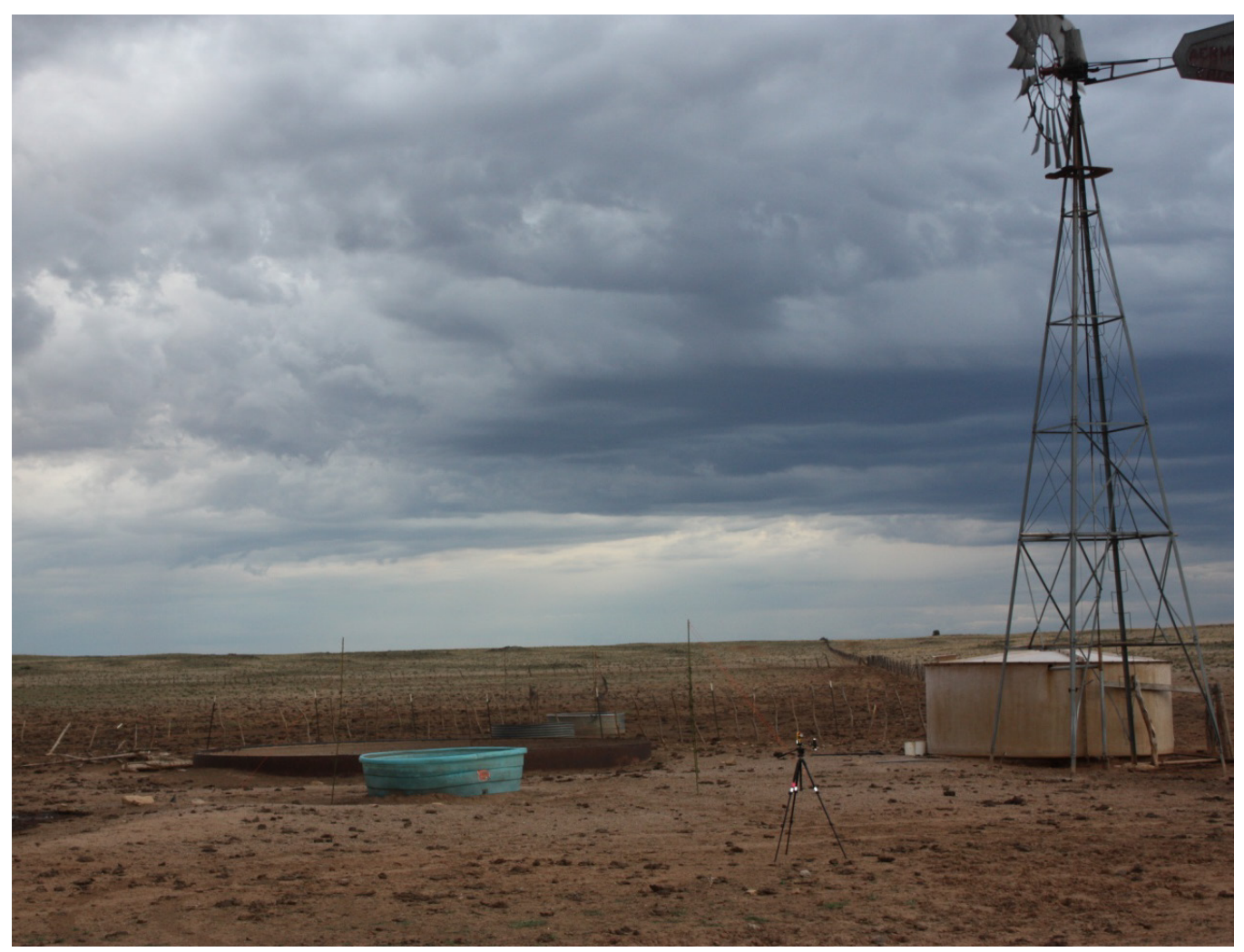

Windmill south of Prairie Dog Well II (Lat 34 $43^{\prime} 59.1^{\prime \prime} \mathrm{N}, 108^{\circ} 5^{\prime} 1.5^{\prime \prime} \mathrm{W}$; elev. 7,169 ft (2,185 m); 4 net-nights): This net site is located on BLM land, approximately $2.4 \mathrm{mi}(3.9 \mathrm{~km})$ southeast of Prairie Dog Well, and was netted by Valdez and others (2002). The surrounding habitat is primarily open grassland with distant lava outcrops. At this site, there were four tanks that included two small metal (about $8 \mathrm{ft}(2.5 \mathrm{~m})$ diameter), one large metal $(33 \mathrm{ft}(10 \mathrm{~m})$ diameter), and one small plastic $(9 \mathrm{ft}$ $(2.7 \mathrm{~m})$ diameter). However, only two tanks (that is, one small metal tank and one small plastic tank) had water that could be netted. On July 28, nets were placed over the plastic and one of the small metal stock tanks, but no bats were captured. Wind and rain were the likely contributing factors for lack of captures.

Publishing support provided by:

Denver Publishing Service Center

For more information concerning this publication, contact:

Center Director, USGS Fort Collins Science Center

2150 Centre Ave., Bldg. C

Fort Collins, CO 80526-8118

(970) 226-9398

Or visit the Fort Collins Science Center Web site at: http://www.fort.usgs.gov/ 
